UDK: 78-073-057.875

Original scientific paper

\title{
LISTENING TO MUSIC WITH THE AIM OF DEVELOPING HIGH-SCHOOL STUDENTS’ MUSICAL GULTURE
}

\section{Ivana Senjan}

High School Dr. Ivan Kranjčev

Đurđevac

Republic of Croatia

ivana.senjan1@gmail.com 


\section{ABSTRACT}

Observing society as a whole, the musical needs of an individual are most often manifested through active music playing/making and listening to mostly popular types of music. The development of one's personal musical identity and preference for a certain musical expression starts from the earliest age, and develops and takes shape throughout life. The paper explores the subject of music listening during music education of children and young people from early and preschool education to the end of high school with the aim of gaining an insight into the course of continuous musical development of students in this field. The paper also presents the project "Hit lists of popular music" by the High School Dr. Ivan Kranjčev in Đurdevac which encourages high-school students to use the mass media in order to create so-called "playlists" on music streaming platforms. The results of the survey have thus shown that in the wide range of different musical expressions students can be guided in a controlled way to discover and listen to aesthetically valuable music, and that there is a positive impact on the development of their critical thinking and personal musical identity.

Key words: musical identity, aesthetic education, critical thinking, hit lists of popular music, playlists. 


\section{INTRODUCTION}

At all levels of general music education, the ultimate goal is to develop and shape the musical culture of a person who connects general culture, musical knowledge and interests, and the socio-psychological dimension of the individual with values in music (Robinson, 2009). An individual can develop a personal music culture in several ways: through intrinsic motivation, under the influence of numerous factors (family, society, mass media, cultural contexts, etc.) and through formal, non-formal and informal music education. Observing formal music education, an important place is certainly taken by aesthetic education which encourages students to have an interest and need for music, and which establishes criteria for evaluating quality musical achievements, regardless of the style to which they belong (Dobrota, Reić Ercegovac, 2016). Aesthetic education encompasses the rational, emotional, willing and creative areas, develops intellectual functioning and the ability to observe, remember, reproduce and critically think on which basis personal criteria for the beauty and quality of works of art are formed. Compared to artistic education, which is focused on the professional development of the future artist's competence, aesthetic education has a general educational as well as general cultural character which makes it accessible to everyone (Vukasović, 2001).

The musical activity that greatly influences the development of the individual musical identity ${ }^{1}$ of children and young people during pre-school education and through the teaching of music in primary and secondary schools, is music listening. In order to achieve an aesthetic experience while listening to music, it is necessary to develop the best possible perception of music in students through an analytical and critical approach. In this way, students can better understand the songs they listen to, form personal musical preferences and develop a lasting need for musical experiences in everyday life. They will also be able to set objective criteria for evaluating music, shape their identity as music listeners and develop musical taste as part of their personal music and culture in general.

The development of critical thinking is increasingly set as one of the goals in the field of modern education due to the significant contribution of the transition from traditional education to the so-called advanced education. Instead of gathering and accumulating lots of information (Knowles, 1980; Paul, 1993; Whitehead, 1929/1967; as cited in Johnson et al. 2011), the main goal of education

1 Identity is defined as the thinking traits and notions that people have about themselves. There are three forms of identity: individual, social and cultural identity. Individual identity represents the unique sense of personality that each individual possesses. The notion of social identity implies a collective sense of belonging to a group. Cultural identity refers to the feeling of belonging to a certain ethnic, cultural or subcultural group (Dobrota, Kuščević, 2009). 
should be to develop a quality thinking process that addresses the needs of $21^{\text {st }}$ century students in order to achieve higher social and cultural goals (Klooster, 2003; Paul, 1993). Although students of all ages can think critically because they already have rich life experience and abundant prior knowledge for further more complex thinking, critical thinking in teaching is unfortunately still more present in theory than in practice (Buchberger, 2012). Likewise, since students' ability to understand and process information does not keep pace with the vast resources available to them (Meyers, 1986), Wegner suggests that teachers teach students through as inventive topics as possible based on thinking and discussion with a view of a critical approach in order to shift the pedagogical focus from content to cognition (Wegner, 1989; as cited in Johnson, 2004).

In music education and the field of music listening, the processes of comparison, evaluation, reflection, judgment and classification point to the need to develop students' critical thinking (Bundra, 1993) because learning about musical works often includes elements of general and subject-specific thinking (Woodford, 1995). Effective music listening pedagogy should develop students' experience in music listening including feelings and thoughts expressed through the music medium (Tait, Haack, 1984; as cited in Johnson, 2004), but the development of multimedia and digital technology has changed the nature of listeners' musical experiences. The contemporary music listeners thus have unlimited access to heaps of information and a large selection of music that they most often choose according to their own preferences (Johnson, 2004) or passively consume it (O'Brien, 1987; Sims, 1990). Frith (1996) points out that musical experiences have become increasingly individualized, which is reflected in one's personal choice of compositions among many musical styles and genres, as well as in personal musical decisions and judgments about the work being listened to (Johnson, 2004).

Observing the existing problem of young people's decadence of cultural identity in the Republic of Croatia, which is visible through the large increase in the population of children and young people who listen to compositions of low value of text, music, arrangement, performance, or visual content, it is obvious that all the aspirations of aesthetic education in music teaching do not achieve the set goal of educating a critical and competent expert and listener of music by listening to valuable musical works (Rojko, 1996). Numerous aesthetically valuable compositions that are listened to from early and preschool education, through primary school and ending with high school, do not set criteria for many students when it comes to the choice of music in everyday life. Students associate art music listening exclusively with music class, while in their free time they listen to their favorite composition only once or do not listen to such a musical expression at all. 
The reason for that is that students do not associate art music with their personality, feelings and mood, which have been proven to be the most influential factors in choosing to listen to music (Senjan, 2018b). Dobrota cites research whose results indicate that students in school search for music similar to the one they listen to outside of school and that students do not see a connection between "real world" music and school music and therefore try to exclude themselves from school music (Ericsson, 2002; Green, 2008; Hanley, Roberts, 2003; as cited in Dobrota, 2016).

Therefore, the question arises whether the existing methods of aesthetic education are effective. Another issue involves adequate listening strategies in music teaching and the need to develop the concept of forming the musical identity of students. Further, the question arises whether critical thinking is carried out at all in music teaching, especially the kind which focuses on the field of popular music and the formation of attitudes while perceiving music of low aesthetic value. Finally, the question of the effectiveness of the amount of lessons of Music Culture/Art, which "tries" to unite the fields of theoretical and musicological contents (music literacy, music history, analysis of musical-expressive components, musical forms and types), listening, learning about and analyzing music with the development of musical abilities (performing music, singing by ear, improvised rhythmics), creativity and interest of students (movement with music, dancing, playing, creativity, musical games, working with a computer, etc.). Certainly, music teaching should through discussions and professional, argumentative guidance of teachers, enable students to independently form an objective opinion on music imposed on them in society and the media, and direct them to independently discover valuable music, regardless of genre.

\section{MUSIC LISTENING IN THE EDUCATION OF CHILDREN AND YOUTH}

If we observe the area of music listening through the entire educational vertical, it is evident that this activity is an indispensable element of music education for children and youth in Croatia. In early and preschool education, music listening is present as a regular activity that strengthens the development of cultural awareness and expression necessary for lifelong learning (National Curriculum for Early and Preschool Education, 2012). Music listening is accompanied by different kindergarten activities every day, depending on the children's age group. Hence, music is listened to with a particular topic or project, such as dancing and singing activities with different musical games (supertalent, karaoke, etc.). Although the songs recorded on CDs are the most present medium in the official and personal 
sound library of educators, it is evident that with the development of technology, music is most often chosen through the music platform YouTube, and the selection of songs is performed by children or singers who have arranged children's songs. A present problem in Croatia is that there are many children's songs on YouTube that when it comes to rendition are not adapted to the range of children's voices ${ }^{2}$, songs that have a poor arrangement ${ }^{3}$, and even arrangements of famous songs where the singing is out of tune $\mathrm{e}^{4}$ or not in the spirit of linguistic and cultural identity, something that should be made aware of from the earliest age of the child. For the purposes of background listening, educators use the daily programme of a radio station (e.g. Otvoreni radio) or instrumental compositions that accompany a certain activity of children (while reading a story or making worksheets). In practice, the analysis of listened compositions according to musical-expressive components or listening to art music at kindergarten age is a rare activity, and music listening is rather associated with singing, reciting counting songs or dancing 5 .

In primary school, music listening began to be practiced more intensively in the 1950s with the development of music-playing devices (gramophones, cassette players, CD players), while in 2006/07 listening and learning about music became mandatory and the main area of the so-called open model of teaching Music Culture (Croatian National Education Standard - CNES, 2006). By adopting the official plan and programme of music teaching in high schools in the school year of 1954/55, the focus of Music Art class, after a long period of singing, learning notes and theoretical overview of music history, gradually shifted to music listening in order to learn the chronologically arranged musical stylistic periods according to the so-called diachronic model.

In the new Curriculum of the subject Music Culture for Primary Schools and Music Art for High-schools (2019), the teaching areas are divided into three domains: A) Listening to and learning about music, B) Expressing oneself through and with music, and C) Music in context. The domain of listening to and learning about music has three outcomes in which students (depending on the grade/cycle/ level) need to be familiar with a certain number of compositions/movements/

2 Example of a song not adapted to the range of children's voices available on: https://www.youtube.com/watch?app=desktop\&v=3hfOWg4jcII\&ucbcb=1 (1/6/2021)

3 Example of a song not adapted to the range of children's voices available on: https://www.youtube.com/watch?v=nflg61aWgKQ\&list=PLF_h5O_XwJ4Zu-meNJQG3uusYo_ SL4G8C (1/6/2021)

4 Example of a song not adapted to the range of children's voices available on: https://www.youtube.com/watch?app=desktop\&v=s7lgg7vzA5E (1/6/2021)

5 Data on music listening in kindergarten: oral source of teachers Markovica, D. and Švetak, T., DV (kindergarten) Maslačak, Đurđevac (personal interview, March 15, 2021) 
fragments of different types of music (classical, traditional, popular, jazz and film music) and analyze individual musical-expressive components as well as form structures and aurally recognize and analyze the characteristics of music periods, musical directions and genres. As one would expect, from lower to higher grades, the musical vocabulary gradually develops, and musical knowledge and knowledge about music (Rojko, 2007) deepens, and ultimately at the end of the fourth grade of high school the student should theoretically and aurally know/be able to recognize musical-expressive components (meter/age, tempo/pulse, dynamics, pitch, colour/ performers, atmosphere, rhythm, melody, tonal structure, scale types, harmony, musical syllable, musical form), all groups of instruments and all instruments, singing voices, chamber ensembles (duo, trio, quartet, quintet), composition of a standard orchestra and all types of choirs. Moreover, during listening they should follow with understanding the binary, ternary and complex ternary forms, rondo, themes with variations, sonata form, recognize musical features of the suite, sonata, concert, symphony, symphonic song, solo song, piano miniature, fugue, oratorio/ passion, cantata, mass/requiem, opera, operetta, musical, ballet and stage/theater music. Furthermore, the student should be able to distinguish the characteristics of music periods (Middle Ages, Renaissance, Baroque, Classicism, Romanticism, Realism, Verism, national styles, Impressionism, Expressionism, Neoclassicism, minimalism, crossover, fusion) and some other musical styles, directions and genres, famous biographies of composers and finally, be familiar with the works of at least 10 prominent composers.

Moreover, by analyzing and elaborating the outcome of knowledge of a certain number of compositions, a good student in primary school should be familiar with 3-10 complete compositions/movements/fragments in the first, second, third, fourth and fifth grade; 5-12 compositions in the sixth grade and 5-15 compositions in the seventh and eighth grade. In total, at the end of primary music education, the student should know at least 92 compositions from the field of classical, traditional and popular music.

In high school, the greatest emphasis is on classical music, which for four (two) years follows the course of music development through history with a number of traditional, popular, jazz or film music. At the level of achievement, a good student should know 10-30 complete compositions/movements/fragments in each grade, i.e. a total of 120 compositions after four years of music education.

In the current textbooks that follow the curriculum of the subject Music Culture/Art, the offer of compositions for listening is rich and diverse, so that in order to teach music, teachers certainly have a great opportunity to choose numbers to follow the (proposal of the) curriculum. An additional advantage is 
that the sound recordings are available on the websites of individual publishing houses, i.e. on platforms with digital and multimedia content that complement the contents of textbooks (IZZI, Mozabook).

Analyzing the number of offered compositions for listening that accompany music lessons from the first to the eighth grade of primary school and from the first to the fourth grade of secondary school, which are available on the website https:// www.profil-klett.hr/ of the publishing house ProfilKlett (Table 1), it is shown that during primary and secondary general education it is possible to listen to a total of 1.021 songs as part of music lessons, but also in the students' private time. This fact shows that students are exposed to music of high aesthetic value throughout their general music education and that teaching music can be a great incentive for them to appreciate art in everyday life and have the need to listen to music of high aesthetic value regardless of genre.

Table 1. Number of compositions scheduled for listening by grade

\begin{tabular}{cccccccccccccc}
\hline \multirow{2}{*}{ Grade } & 1. & 2. & 3. & 4. & 5. & 6.MS & 7.MS & 8. MS & 1. & 2. & 3. & 4. \\
& PS & PS & PS & PS & PS & HS & HS \\
\hline Compositions & 100 & 109 & 115 & 91 & 69 & 87 & 70 & 81 & 103 & 63 & 47 & 86 \\
\hline Total number & & \multicolumn{10}{c}{1.021} \\
\hline
\end{tabular}

After a rough insight into the systematically organized plan for the development of students' music culture in the field of listening to music, we ask ourselves how much music teaching can really develop/shape the musical taste and musical identity of an individual.

Sloboda and O’Neill (2001; as cited in Dobrota, Reić Ercegovac, 2016, 48) point out that "music listening always takes place in a social context, at a certain time and place, with or without other individuals and simultaneously with other activities that have their own meanings and sources of emotions...", thus indicating the complexity of this area due to the large number of different factors that affect the aesthetic perception and musical preferences of the listener. Hargreaves, MacDonald and Miell (2005) in the Reciprocal Response Model discuss three influencing factors on the listener's musical taste that interact with each other: the listener (individual differences, musical knowledge and experience, listener's musical identity, upbringing, attitudes, etc.), situations and context in which the listener finds himself (social and cultural context, everyday situations, presence and absence of other people, various activities during listening, etc.) and about the characteristics of music (musical-expressive components, various styles and genres, familiarity with and complexity of music). Likewise, many authors identify that the 
way, type or strategy of listening ${ }^{\mathbf{6}}$ is a crucial factor in the perception of music and the formation of the typology of the listener. They start off from the basics of the communication process that divides listening methods into informative listening (message comprehension is based on vocabulary, concentration and memory), relationship listening (compares the quality of presentation, attitudes about perception and previous experiences), critical listening (based on argumentation) and discriminative listening (detects differences between sounds, sensitivity to pauses, etc.) (Kline, 1993). When it comes to music listening in music teaching, the emphasis is on learning, observing and studying the musical-expressive components of the work: melody, rhythm, harmony, dynamics, agogics, musical form, connection of words and music, etc. Therefore, it is necessary that a whole series of musical activities be realized before, during and after listening to the composition, which Požgaj $(1950,5)$ defines according to the following schedule:

1. preparation for listening (pre-work, creating the mood);

2. experience of a musical work (listening to music, aesthetic enjoyment);

3. comprehension (observation of expressive elements, mental comprehension of the content);

4. expressing opinions and reasoning;

5. conversation and teaching (theoretical, technical, formal, stylistic and historical notes);

Following such an approach, the understanding of a work of art certainly becomes clearer to students. Still, if there is no appropriate listening strategy, then understanding, aesthetic experience and positive impressions of the composition will be lacking.

The most common division of music listening refers to the activity of the listener, which is divided into active and passive listening (Rojko, 1996). Active listening, which is necessary for the correct understanding and experience of a musical work, implies the effort and conscious activity of the listener to find

6 Depending on the strategy of music listening, but also many other factors (for example the listener's degree of musical culture, upbringing, personal components, personal attitudes and preferences) a typology of listeners is formed that determines the quality of musical experience. Thus Adorno (1962) defines eight types of music listeners: the musically indifferent, the emotional listener, the resentment listener, the listener to whom music is entertainment, the jazz specialist, the culture consumer, the good listener, the expert. Given the attitude of listeners towards the music of his time, Andreis (1967) classifies listeners into conservative and progressive. Kemp (1997) analyzes the attitude of listeners towards certain musical genres (some listeners prefer symphonic rather than chamber music, others opera music, still others solo concerts, etc.), composers, stylistic periods and certain musical-expressive components. 
meaning in the musical material, notice the musical-expressive elements of the work, compare them, consciously follow the sound flow and gradually build a scheme of the musical form. It presupposes the listener's engagement, concentration, memory, and ability to compare, piece together, differentiate, and synthesize music. It is aimed at acquiring musical knowledge and skills. Unlike active listening, passive listening is present in those listeners who lack the abovementioned characteristics and for whom listening is only a physiological process of receiving sound stimuli without consciously focused attention and activity (Škojo, 2010). Passive listening is spontaneous listening and can affect the mood.

In addition to the division into activity while listening to music, Rojko (1996) defines listening strategies that relate to the listener's attitude in the perception of music. The listener's attitude can be emotional, rational, concentrated on the perceptual field or focused on musical or non-musical references. Thus there is listening as knowing and understanding a problem; listening concentrated on details and on the whole; intrinsic listening (focused on musical elements without external associations), extrinsic listening (evokes non-musical associations), and listening as meditation. Furthermore, Alt (1973; as cited in Rojko, 2012) categorizes listening to music as sensory listening (sensory, motor and emotional reaction), aesthetic listening (active and conscious, intellectual and subjective-interested attitude) and imaginative listening (focus on non-musical contents).

Cook suggests that there are two types of listening in music teaching: musical listening for the purpose of direct aesthetic experience and pleasure, and musicological listening for the purpose of discovering technical facts, information and forms in order to set theory (Cook, 1990; as cited in Rentfrow, Gosling, 2003). Similar to Cook's division, Rentfrow and Gosling (2003) also highlight two types of listening: pedagogical or practical listening, which is used to determine the elementary parts of a song that is heard or performed. The second type of listening is experiential listening aimed at musical pleasure. Pedagogical listening is the one practiced in schools with active music playing, where students listen to the harmony of performance, accuracy of intonation and many other parameters, with the aim of better performance of the ensemble in which they play or sing. This kind of practical listening develops the listener's perception and increases the aesthetic response.

Dobrota and Reić Ercegovac (2016) cite contemporary strategies for listening to music, directing them towards the listener, i.e. towards the music itself. Thus, in the first group, the listening strategy related to the listener, Hedden (1973) defines cognitive and associative strategy, which coincides with Smith's (1987) argument that the fundamental difference between listening to music by musicians and "non- 
musicians" is that "non-musicians" have an emotional and referential approach, while the musician uses a syntactic strategy in which analytical and musicological processes take precedence. The second group of research on listening strategies includes research that focuses on music itself. For example, Hagerty (1983; as cited in Dobrota, Reić Ercegovac, 2016) believes that liking a song declines if it is similar to the one just listened to, while Beckler, Allen, and Konečni (1985), after experimenting with the perception of music and pictures, concluded that the participants chose to expose themselves to unpleasant music and pictures first, while keeping pleasant music and pictures for the end.

In the field of cognitive-emotional listening, Hargreaves and Colman (1981) distinguish between objective-analytical and affective music listening. Objectiveanalytical listening involves the objective attitude of the listener directing his attention to the analysis and observation of musical-expressive elements, while affective listening implies the emotional attitude of the listener, simple and naive. Surkova (2012) also divides music listening in music education into emotional listening and analytical listening. The former is related to feelings and imagination, which does not presuppose musical knowledge or musical talent. The latter presupposes musical knowledge and is associated with musical-expressive components. However, the author emphasizes that analytical and emotional listening cannot be clearly separated because they are in constant interaction. Therefore, to assess the emotional impact of music on the student, the author suggests that the nature of the music itself, the emotional state and the musical readiness of the students be considered. In other words, the way of listening can be directed and dependent on what is being listened to, who is listening and what is the psycho-affective state of the person while listening to music. The social context of the listener should also be considered, linking it to the time and place, where and why they listen to music.

The process of music listening in teaching is carried out by different methods and forms of work. In order to avoid passive listening, students should exercise basic attention before listening to a song (Madsen, Geringer, 2000/2001). After evoking the appropriate emotional state and mood for listening, students will be given the appropriate tasks that most often relate to the musical-expressive components. The tasks should stimulate students' concentration and interest and serve them "as an aid in navigating through an abstract piece of music, as strongholds around which they direct their attention" (Dobrota, 2012). In addition to student activities, active teacher involvement is required. While listening to music, the teachers should not do anything else that would distract their attention, but also the attention of the students while listening. By their example they should rather show the students the 
way music is listened to (Šulentić-Begić, 2006). To experience the work and notice all the musical components requires repeated listening. The issue of multiple listening has been examined in many studies. Gilliland and Moore (as cited in Rojko, 1996) found that by repetition, classical music compositions become more popular, while in pop music the opposite happens. That is to say, that the comfort of repetition grows in compositions of greater aesthetic value. Vidulin-Orbanić (2002) points out that by repeatedly listening to musical works, students notice "hidden" details that they are not able to notice during the first listening. That is why Šulentić Begić (2006) emphasizes that between two listenings it is necessary to have a conversation with the students about what has been observed, which will interest them and additionally encourage them to the next listening.

Among other methods of listening to music, Surkova (2012) proposes a research and analytical method that enables the discovery, connection and analysis of one's own music experiences through listening. Moreover, the discussion helps to discover musical experiences among students, the essay belonging to the discussion method allows for written self-expression, while the project method allows for a systematic and organized implementation of musical experiences. The author also points out that adolescents base their attitude towards music on the criteria of their own values, so listening to music in class should motivate students to discover the value of listening to quality music, socializing and innovation. Consequently, music listening would become an action process with the aim of gaining a quality musical experience.

\section{METHODOLOGY}

\section{Problem and goal}

The musical culture of high school students is greatly influenced by the mass media, which directs them towards popular music placed according to market rules, regardless of culturally higher goals (Šuran, 2013; as cited in Škojo 2019). Hence, students most often consume the music that is imposed on them or choose it without a personal critical attitude. It is precisely in this direction of the development of critical thinking, musical taste, musical identity and finally, the development of the musical culture of students that the project "Hit lists of popular music" was realized. The project focused on the popular types of music because it wanted to directly raise the criteria for selecting the music that is most common in the students' free time. 
The aim was to examine the difference in attitude between younger and older high-school students about whether making and listening to hit lists of popular music (hereinafter playlists) affects the development of the students' musical taste and musical identity.

The task was to select songs and create playlists ${ }^{7}$ of famous domestic and foreign hits of popular music on the streaming platform Spotify ${ }^{8}$. In accordance with the task, the following hypotheses are set:

$\mathrm{H} 1$ : There is no statistically significant difference between younger and older students in the view that the "Hit lists of popular music" project affects more intensive listening to aesthetically valuable music in students' free time.

$\mathrm{H} 2$ : There is no statistically significant difference between younger and older students in the view that the "Hit lists of popular music" project develops students" critical thinking in the field of listening to music.

H3: There is no statistically significant difference between younger and older students in the view that the "Hit lists of popular music" project develops students" musical taste and musical identity.

H4: There is no statistically significant difference between younger and older students in students' openness to making and listening to playlists of aesthetically valuable music.

\section{Participants}

The project "Lists of hits of popular music" was carried out in the High school Dr. Ivan Kranjčev in Đurđevac in the school year 2020/2021 as part of Musical Art class. The duration of the project was five months, more precisely from midOctober 2020 to mid-March 2021.

The project involved all students of the high school $(\mathrm{N}=159)$ from 1st to 4th grade, a total of eight grades and the age group from 15 to 19 years of age, but the final examination was conducted on a sample of 155 students because not all students approached the survey. Table 2 shows the structure of the sample, where the first (younger) group consists of first and second grade students, while the second (older) group consists of third and fourth grade students.

7 A playlist (according to the Cambridge Dictionary) is a list of musical works that an individual has chosen to listen to on their computer, cell phone, and so on.

8 Spotify is the largest and most popular music streaming platform, founded in 2008 in Sweden. It provides free access and listening to millions of songs, as well as creating personal playlists via computers or mobile devices. Spotify has been available in Croatia since July 14, 2020. 
Table 2. Sample structure $(\mathrm{N}=155)$

\begin{tabular}{|c|c|c|c|c|}
\hline \multirow{2}{*}{$\begin{array}{l}\text { GROUP: } \\
\text { GRADE: }\end{array}$} & \multicolumn{2}{|c|}{1.} & \multicolumn{2}{|c|}{2.} \\
\hline & 1st grade & 2nd grade & 3rd grade & 4th grade \\
\hline \multirow{2}{*}{$\begin{array}{l}\text { NUMBER OF } \\
\text { STUDENTS: }\end{array}$} & 46 & 40 & 31 & 38 \\
\hline & \multicolumn{2}{|c|}{86} & \multicolumn{2}{|c|}{69} \\
\hline \multirow{2}{*}{ GENDER: } & \multicolumn{4}{|c|}{$M=52$} \\
\hline & \multicolumn{4}{|c|}{$\mathrm{F}=103$} \\
\hline TOTAL: & \multicolumn{4}{|c|}{155} \\
\hline
\end{tabular}

\section{Instrument}

For the needs of the research, a questionnaire was created, which consisted of a total of 19 questions. In the first part of the questionnaire, after defining the basic socio-demographic characteristics of the participants (gender and age), students had to answer questions about how many hours a week they listened to music, whether they had already established personal playlists on a computer, mobile phone or one of the platforms for music listening (Spotify, YouTube, Deezer, etc), which of the popular playlists of popular music they liked the most, whether they listened to turbo-folk/narodnjaci, trap-cajke, Balkan trap-folk, rapfolk, fusion trap or Croatian/Balkan pop music of lower/low quality lyrics, music, arrangements or performance, and whether they had reduced the need to listen to such musical expression in relation to previous music listening of lower/low aesthetic value. In order to confirm or reject the hypotheses, in the second part of the questionnaire students had to answer 12 statements that referred to attitudes towards the project "Hit lists of popular music" in Music Art class. The answers were to be ranked according to the Likert scale, with number 1 expressing the opinion I strongly disagree, number 2 I disagree; number 3 neither agree nor disagree; number 4 I agree and number 5 I strongly agree.

Thus, for the first hypothesis, attitudes were examined as to whether the project helped students combine a number of aesthetically valuable popular songs that they liked, whether they discovered new quality performers and songs that they began to listen to during the project, and whether the project confirmed that they wanted to listen exclusively to aesthetically valuable music. For the second hypothesis, attitudes were examined as to whether students thought critically when selecting compositions and creating personal playlists, whether they developed a sensitivity to recognizing aesthetically valuable popular music during the project, and whether the project encouraged them to have a critical approach as to what music had to offer in society and media. For the third hypothesis, attitudes were 
examined as to whether they felt that the project had a positive effect on the development of their musical taste, whether the project determined that they did not want to listen to music of lower/low aesthetic value, and whether they planned to continue making and listening to aesthetically pleasing music regardless of genre with the goal of shaping their personal musical identity. For the fourth hypothesis, attitudes were examined on whether the students solved the tasks of selecting songs and making playlists during the project with interest, whether they planned to listen to playlists that have been established (jointly and independently) for this project and whether they wanted to continue developing the "hit list project" with other genres of music (film, musical, jazz, ethno, crossover, classical music, etc.).

\section{Research procedure}

The project manager first offered the students 200 compositions, each of which selected about ten preferred compositions. Moreover, each student had to suggest, according to their own choice and according to the criteria of aesthetically valuable music, 10 compositions from the field of pop-rock domestic and foreign music, musical expression of the 1950s, 1960s, 1970s, 1980s, 1990s, 2000s to the present day or in the fields of jazz, musicals, film music, French and Croatian chansons, hits, Italian canzones, Russian romances, starogradska muzika, traditional Croatian and country music, rap/hip-hop, techno/dance, grunge, metal, religious music, world music, ethno and crossover music. The classification and proposal of genres was proposed by the teacher herself, according to the specifics of musical expressions and directions in a popular type of music that students occasionally or never listen to in their free time ${ }^{9}$. The compositions chosen by the teacher and to be chosen by the students were to be hits and should not have had the characteristics of less valuable music or directions ${ }^{\mathbf{1 0}}$. Moreover, students could suggest songs that they listened to in their free time, only turbofolk and trap-cajke were out of the question. As previous research on the preferences of the secondary school population in Croatia has shown (Brđanović, 2014; Dobrota, Reić Ercegovac, 2009; Dobrota, Senjan, 2018; Dobrota, Tomić Ferić, 2006; Senjan, 2018b; Škojo, 2016; Škojo, 2019), selection was mostly related to domestic pop music, pop, rock and to a lesser extent techno, rap, hip-hop, heavy metal and punk.

9 The division of genres was determined according to a questionnaire in the research (Senjan, 2018c) and after many years of pedagogical work with students which showed that many students did not have familial music education in music listening, knowledge of music hits in the past and pluralism of musical directions, nor the need to discover or listen to them.

10 Less valuable popular music can be recognized by the low level of the text (banal rhymes, inappropriate and vulgar themes), the same melodic-rhythmic pattern, simple form with frequent repetitions, typical melody decorations with exaggerated voice vibrato and arrangements that are examples of kitsch. Such music sets wrong values, creates false images of life and arouses the lowest passions. 
After each student had decided on their playlist of 20 songs and sent it to the teacher for review, a playlist belonging to that class was created and finally, a playlist of all school students with a total of 700 songs. The teacher published playlists called Hits 1, 2, 3 and 4 - students of High School Đurdevac on the Spotify platform under the profile of Ivana Senjan ${ }^{\mathbf{1 1}}$. Moreover, according to her personal choice of songs, the teacher set up lists of domestic and foreign GOLD hits, precisely 300 songs. These are well-known popular compositions that marked the second half of the 20th century and the early 2000s and are threatened with oblivion because students have not had the opportunity to listen to them in their private time, or already have established artists, compositions and genres they prefer, so they do not want/do not have time to explore valuable music from the past.

The project was also joined by teachers/school staff who in their lists combined the hits of their youth and hits that they listen to every day. These lists entitled Hits 1 and 2 - teachers of High School Đurdevac consist of 400 songs. By listening to their teachers' favorite songs, students could get to know them even better, but they could also discover other musical numbers that could develop their openness to different musical expressions. After defining a total of eight playlists on Spotify (Figure 1) that brought together 1.500 music hits, all lists were posted on the school's YouTube channel (Figure 2) so that they could be listened to by interested individuals who are not registered on Spotify ${ }^{\mathbf{1 2}}$.

11 Popular music hit lists are available on: https://open.spotify.com/user/o9wqm5hcoysa4o3x11nxup swl ?si=5bb1228cd03a49cc (1/6/2021) Songs from these playlists were also published on the profile of the more general name Glazbeni putokaz (Musical Roadmap), where there are also playlists of other genres, created as a continuation of this project. Over 2.200 songs were formed in 14 playlists: Croatian children's songs, Music for children, Stories for children, Popular music - domestic hits, Popular music - foreign hits, Retro music, Film music - Soundtracks, Crossover, Musical and operetta, Classical music, Jazz, Traditional and Ethno Music, World Music and Music for Socializing and Dancing. Available on: https://open.spotify.com/user/qz7tu5cjrjowks0pkso03125p?si=8b741cd784c24971 (5/6/2021)

12 Hit lists of popular music are available on the YouTube channel of High School Dr. Ivan Kranjčev Đurđevac: https://music.youtube.com/channel/UCmxIwZjYhnqFkCGgrgkvR1w (5/6/2021) 


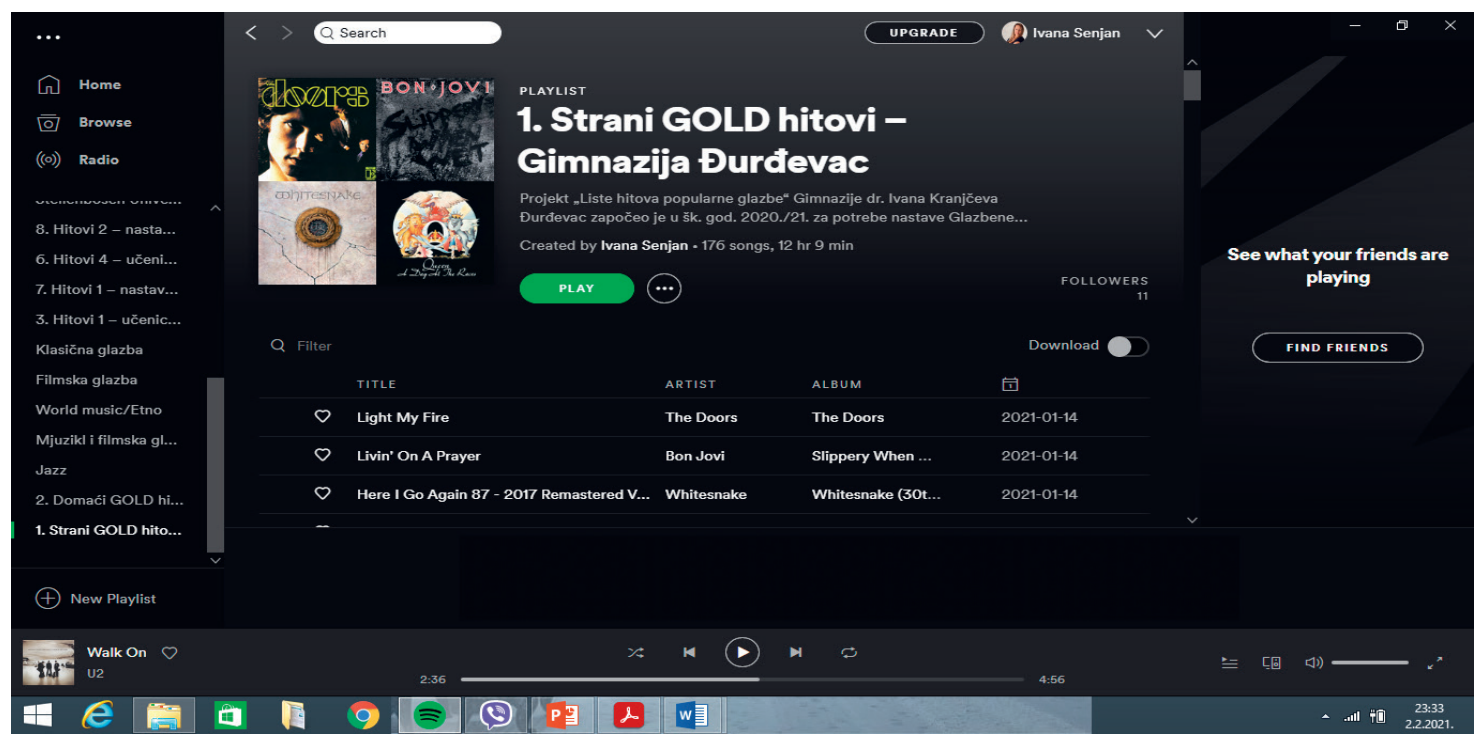

Figure 1. An example of a playlist of foreign GOLD hits on Spotify

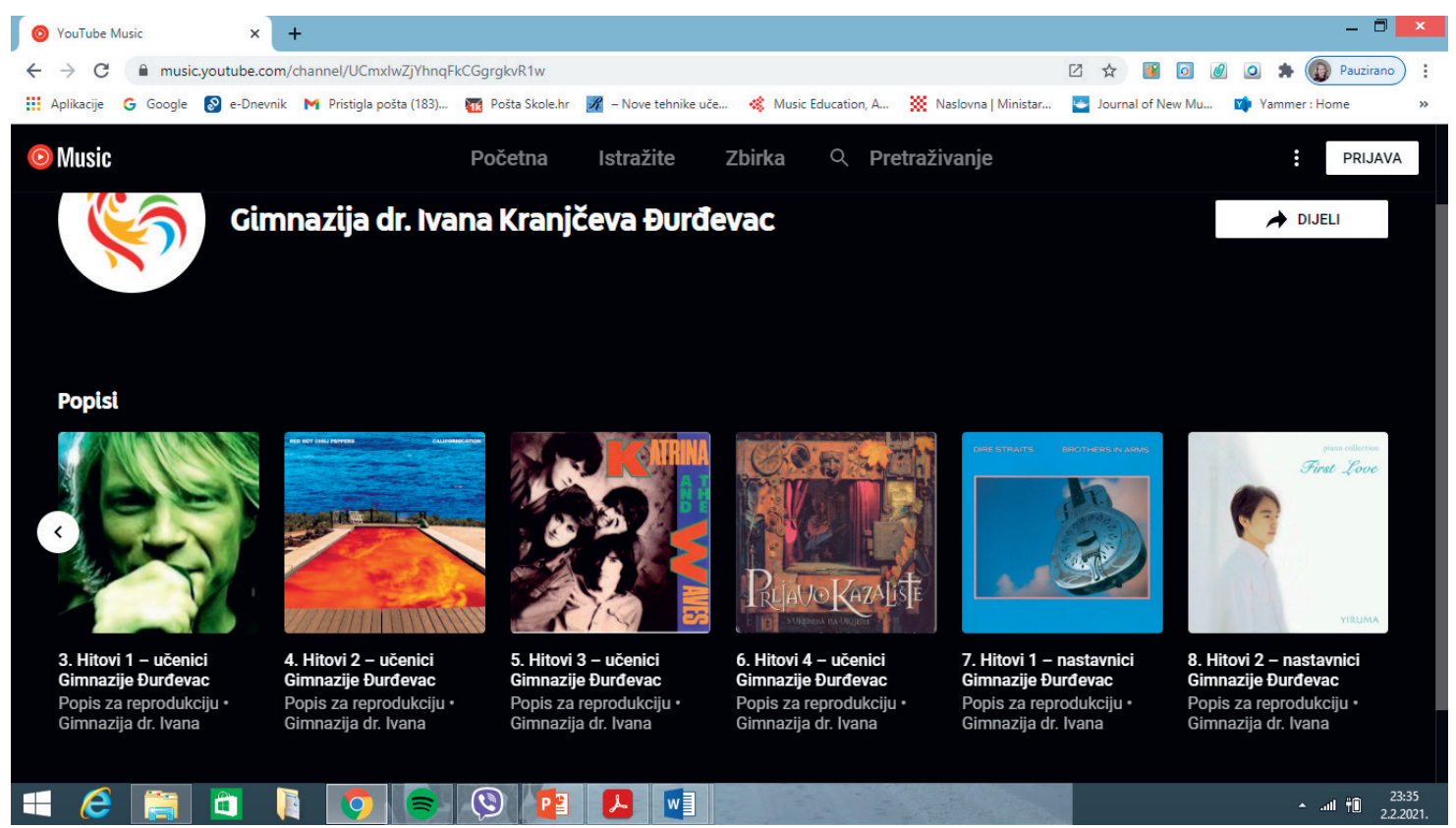

Figure 2. Example of a playlist on YouTube

In the final phase of the project, students had the task of listening to one playlist each week, and based on personal preferences, they had to choose a certain number of songs they liked and place them on their profile in a total of three playlists. The first playlist called GIK-1 $1^{\mathbf{1 3}}$ included a minimum of 100 compositions of domestic and foreign hits, the GIK-2 playlist included a minimum of 150 student hits, while the GIK-3 playlist included a minimum of 100 teacher hits. After the realization of this task, a survey followed.

13 Abbreviated GIK-1 means Gymnasium Ivan Kranjčev, playlist 1 
While creating the playlist, the students had teaching units related to the development of personal musical identity, musical taste and critical thinking throughout the Music Art class. The following teaching units were covered: Ways of listening to music, Typology of listeners, Influencing factors on musical taste and listener's response to music, Hermeneutics in music, Formal and expressive analysis of a musical work, Quality of a musical work, performance and interpretation. In addition, students had to do three homework assignments. In the first, they solved a test on connecting musical preferences with the personality of the listener, entitled The Do-Re-Mis of Personality - What your music tastes say about you ${ }^{14}$. In the second homework, the students had to write the essay My Identity as a Music Listener which established their own approach to music listening and personal identity as music listeners, while the third homework required each student to determine the preference based on selecting and listening to one of the offered compositions and to state and argue at least 10 reasons for liking/disliking the composition, defining the way of listening to the composition and the listener's response to the music. Current popular compositions performed at competitive festivals (Dora, Eurosong) were analyzed in the Music Arts classes, and the students set the criteria for valuable and less valuable musical achievements, both independently and with the objective support of the teacher.

\section{Results and discussion}

The analysis of the answers to the first part of the questionnaire provided general information on music listening in the students' free time. It was found that $46 \%$ of the students listen to music more than eight hours a week, $36 \%$ about eight hours and only $18 \%$ less than eight hours. The data are in line with previous research (Senjan, 2018b), but it is also evident that increasingly more students listen to music for more than an hour a week, which shows the fact that the need for music is an ever-present phenomenon and that students have an increasing need to listen to music during their many everyday activities. The importance of music in the lives of adolescents is also indicated by the results of research by North, Hargreaves and O'Neill (2000) which state that English adolescents listen to music on average 2.45 hours a day.

Further, as many as $83 \%$ of students confirmed that even before the project "Hit lists of popular music" they had their personal playlists on a computer, mobile phone or one of the listening platforms (Spotify, YouTube, Deezer...), while 18\% of students made their personal playlists for the first time because of the project. This data indicates that young people are in step with the development of technology

14 Available on: https://www.outofservice.com/music-personality-test/ (5/6/2021) 
and that they have a need to establish a personal musical expression. The present problem is that on one playlist, in addition to the world-renowned hits or evergreens, one can also find music of low aesthetic value because aesthetic criteria are not taken into account. Jokić (2021) points out that today's young people's musical taste is mostly determined by the characteristic of fluidity, which means that they simultaneously listen to and accept different musical genres. This can be seen in the order of the songs on the playlist on the mobile phone, on which Jelena Rozga is next to the Ramones, followed by Rachmaninov and then Buba Corelli and his 'brother' Jala Brat. From this example, it is possible to conclude that the musical identity of many young people in Croatia is in great ideological conflict.

It was likewise found that out of a total of eight playlists, which are grouped into three categories: domestic and foreign GOLD hits, students' hits and teachers' hits, $63 \%$ of students mostly chose songs from the playlist students' hits when creating their personal playlists, 30\% from playlists domestic and foreign GOLD hits, while only $7 \%$ of students were in the mood to discover the songs their teachers listened to. This data is an indicator that students, despite the large offer of music hits, still remain true to their musical expression because they mostly accept songs that are generationally close to them and those that they independently explore, not those that are offered, imposed or never heard. However, it should be noted that the students' lists contained songs that meet all the criteria of aesthetically valuable domestic and foreign music and that about 200 songs were suggested to students by the teacher, while the other 500 songs were directed by her towards pop-rock domestic and foreign music, musical expression of the 1950s, 1960s, 1970s, 1980s, 1990s, 2000s to the present day, the fields of jazz, musicals, film music, French and Croatian chansons, hits, Italian canzones, Russian romances, starogradska muzika, traditional Croatian and country music, rap/hip-hop, techno/dance, grunge, metal, religious music, world music, ethno and crossover music.

When asked whether they listened to turbofolk/narodnjaci, trap-cajke, Balkan trap-folk, rapfolk, fusion trap or Croatian/Balkan pop music of lower/low quality lyrics, music, arrangements or performances in their free time, $10 \%$ of the students admitted they did, 51\% answered that they occasionally did, while 39\% stated that they did not listen to music of low aesthetic value (Chart 1 ). This data indicates that a large number of respondents (61\% in total) have a need to choose low-value music in their private time or are exposed to listening to such musical expression, be it independent choice, listening at social gatherings or background music during nights out to clubs and cafés. Nowadays, there is a growing interest in the research of musical taste of young people, in which the influencing factors on the preferences of certain music genres are determined, which also include 
turbofolk music and those who listen to such a genre occasionally and those who do not. Therefore, sociologists from the Department of Sociology of the University of Zadar conducted a research in the six largest cities on the Adriatic: Rijeka, Pula, Zadar, Šibenik, Split and Dubrovnik. The research was conducted on a sample of 2.650 high school students. Regarding turbofolk, similarly to this research, the results showed that in Croatia $41.3 \%$ of respondents prefer turbofolk, $16.5 \%$ have no opinion about turbofolk, and $42.2 \%$ of young people point out that they do not like turbofolk (Kalauz, 2018)

The answers to the last question of this part of the questionnaire found that after the project "Hit lists of popular music" in Music Arts class 16\% of the students did reduce the need to listen to aesthetically lower/low music, 34\% did so partially, while $11 \%$ remained unchanged. As in the previous question, $39 \%$ of the students confirmed that there was no need to reduce it because they did not listen to low quality music anyway (Chart 2 ).

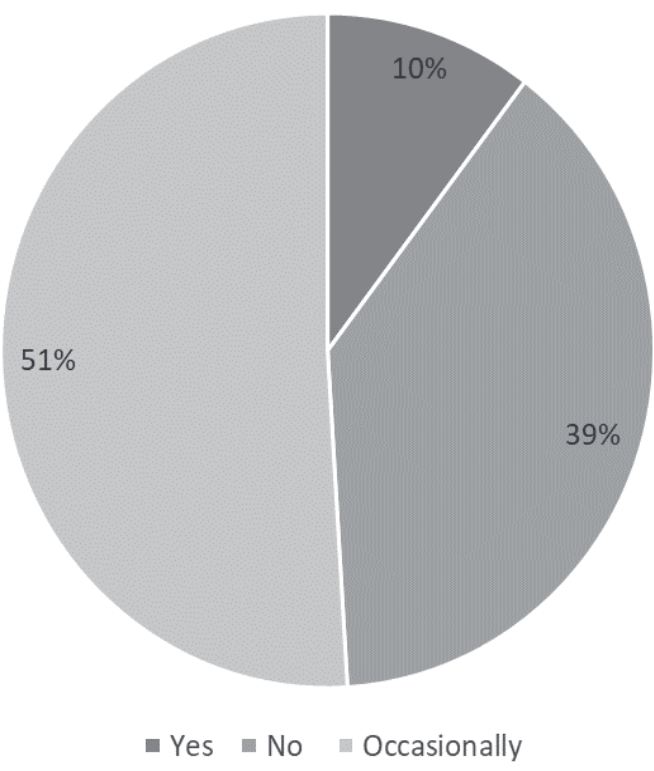

Chart 1. Answers to the question "In my free time I listen to turbo-folk/narodnjaci, trap-cajke, Balkan trap-folk, rapfolk, fusion trap, etc. or Croatian/Balkan pop music of lower/low quality lyrics, music, arrangements or performances" 


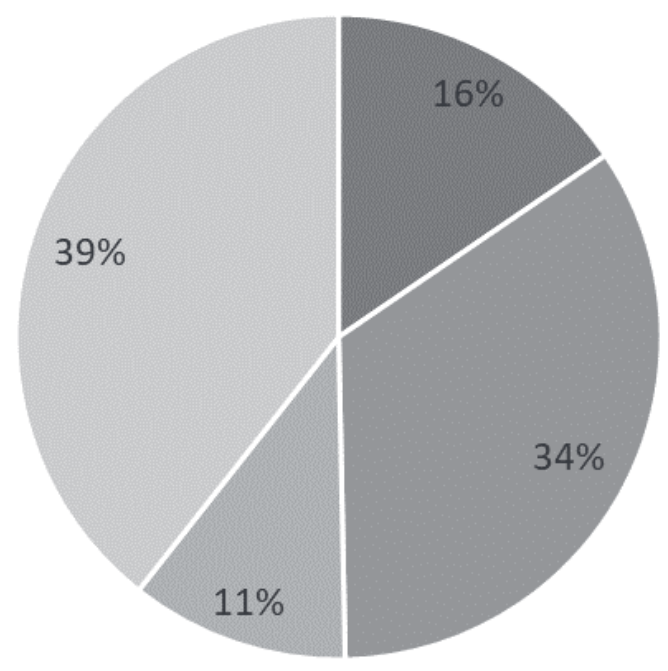

- Yes

- Occasionally

No

I I don't listen to music of lower/low aesthetic value at all

Chart 2. Answers to the question "Compared to previous listening to music of lower/low aesthetic value, after the project I have reduced the need to listen to such expression"

In order to determine the positive impact of the project "Hit lists of popular music" on the students' musical taste and musical identity, the second part of the questionnaire examined a total of 12 statements for each hypothesis with three questions to compare the younger group of students made up of 1st- and 2ndgrade students with an older group comprising 3 rd- and 4 th-grade students.

H1: There is no statistically significant difference between younger and older students in the view that the "Hit lists of popular music" project affects more intensive listening to aesthetically valuable music in students' free time.

To test the set hypothesis, the Mann-Whitney $U$ test was calculated. The results indicate that there is no difference in attitudes on the project "Hit lists of popular music" affecting more intensive listening to aesthetically valuable music with regard to age/grade of the students (Table 3, Figure 3). Thus, the hypothesis was confirmed. 
Table 3. Differences in attitudes about the impact of the project "Hit lists of popular music" on more intensive listening to aesthetically valuable music with regard to age/ grade

\begin{tabular}{|c|c|c|c|c|}
\hline Grade/Age & $\mathrm{C}$ & $\mathbf{U}$ & $\mathbf{z}$ & $\mathbf{p}$ \\
\hline 1st \& 2nd grade HS & 3.99 & \multirow{2}{*}{2832.50} & \multirow{2}{*}{-0.49} & \multirow{2}{*}{0.63} \\
\hline 3rd \& 4th grade HS & 3.98 & & & \\
\hline
\end{tabular}

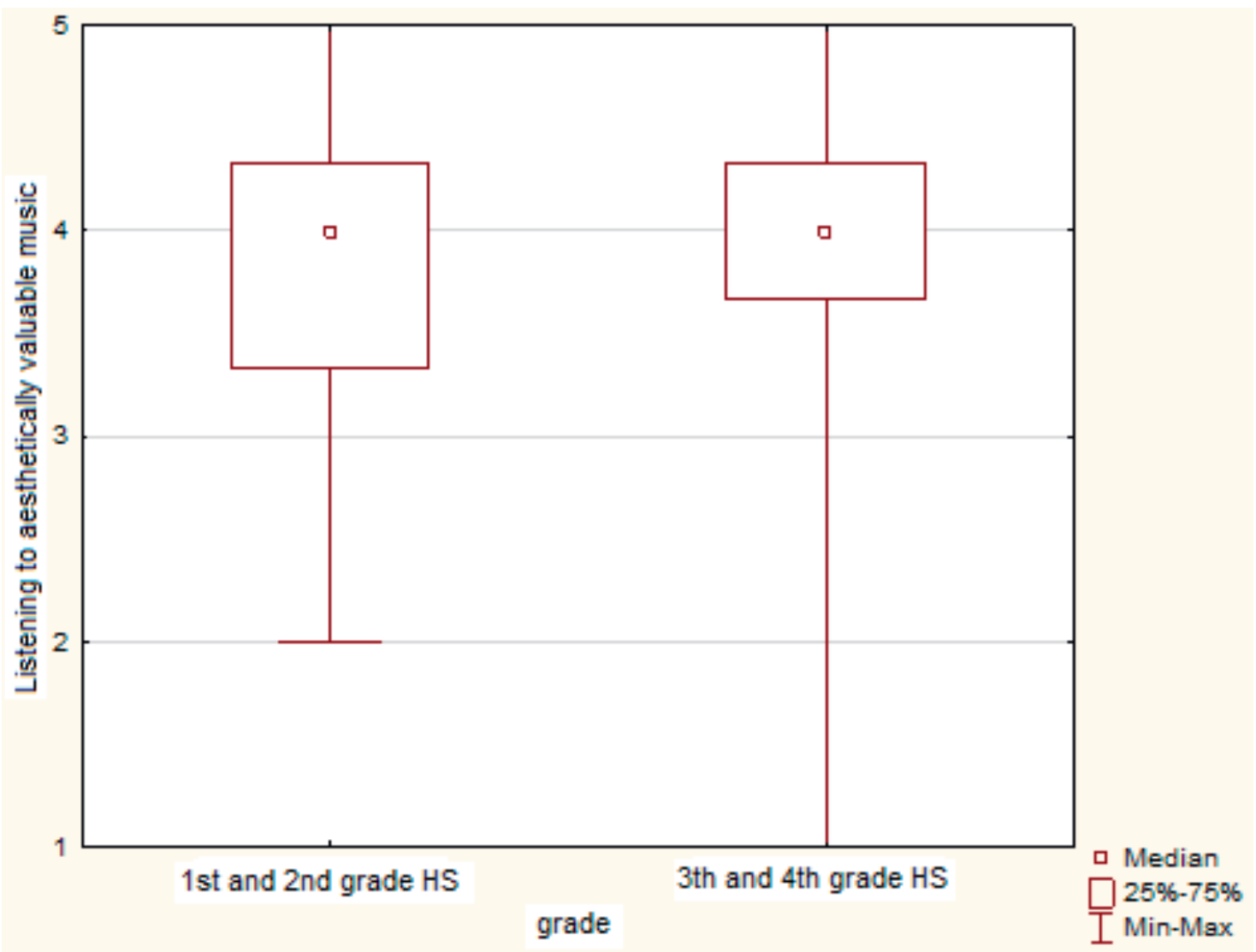

Figure 3. Differences in attitudes on the impact of the project "Hit lists of popular music" on more intensive listening to aesthetically valuable music with regard to age /grade

Moreover, Chart 3 shows a scale of grades from one to five with the calculation of the average percentage of students of the 1st and 2nd group in the answers for a total of three questions of the first hypothesis. The width of the chart of an individual group for a grade determines the percentage of students in a particular group in grading the hypothesis. The difference in the percentages of groups in a particular grade indicates the percent of how many more students in one group gave a hypothesis a grade than students in another group. 


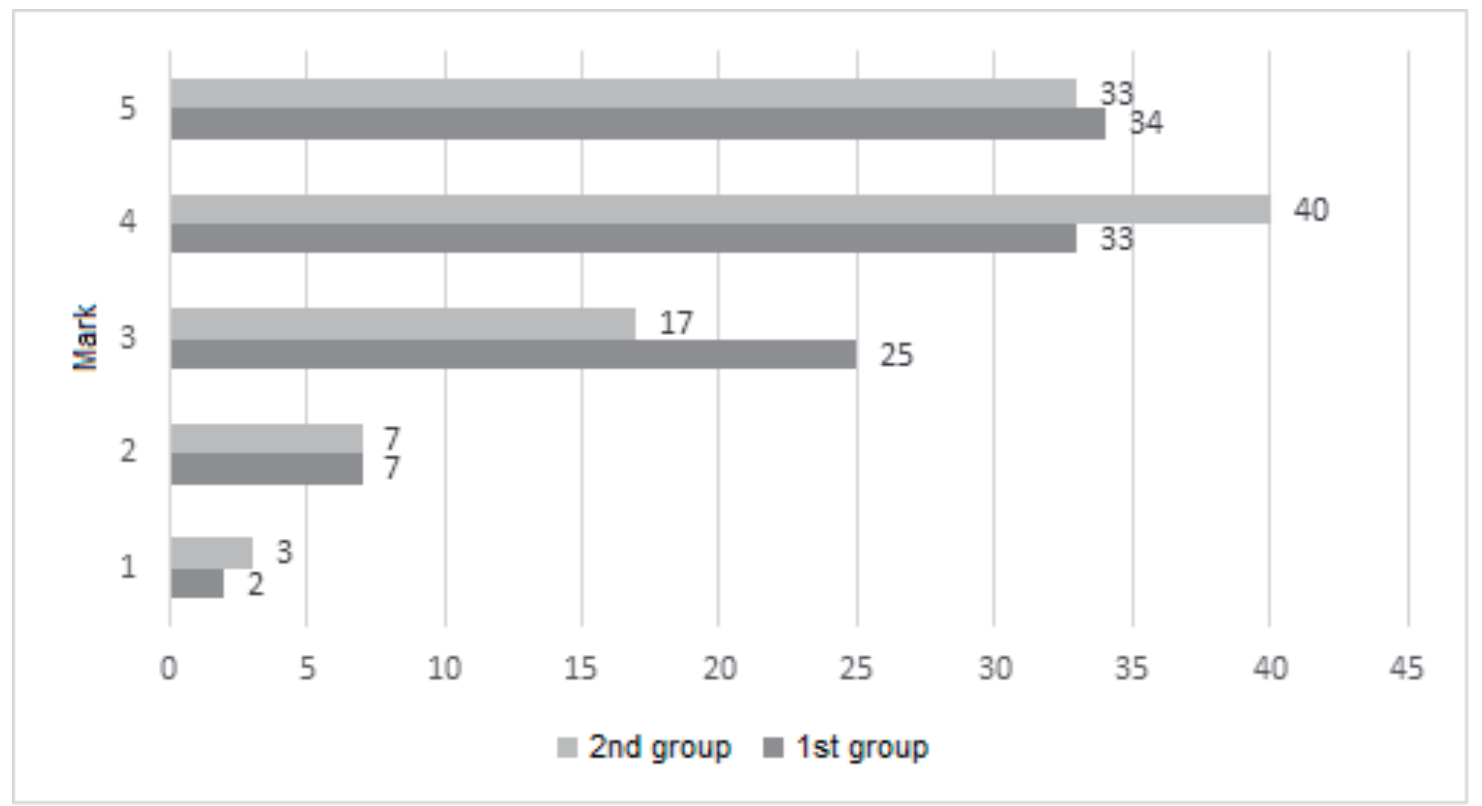

Chart 3. Display of the average percentage of students in groups 1 and 2 in the answers for a total of three questions of the first hypothesis

These results suggest that regardless of age, placing the students in the context of selecting and listening to compositions of high aesthetic value is reciprocal with the development of the need to listen to compositions of high aesthetic value. Further, it was found that the project helped students to have in one place a large number of aesthetically valuable popular songs that they liked, and that most of them during the project discovered new quality artists and songs for which they showed interest in their further listening. Such a way of listening to songs from personal playlists certainly saves the time searching for individual artists and songs on the Internet. The Internet is also the most common medium for listening to music (Senjan, 2018b), but it is also full of poor performances and advertising content that the listener, if not critically aware, loses time on.

By developing a sense of the aesthetic value of music, students develop their perception of the valuable music that surrounds them on a daily basis and develop their musical abilities conditioned, in this case, by music class. When it comes to the influence of music abilities and music lessons on music preferences, research results indicate that individuals with higher levels of music instruction and more developed musical abilities expand musical preferences within different musical styles and prefer more complex music over individuals with lower levels of music instruction and weaker developed musical abilities (Gregory, 1994; Moore and Johnson, 2001; North and Hargreaves, 1995). This is to be expected, given that 
music education and developed musical abilities influence the perception of the complexity of music, which is an important determinant of preferences.

H2: There is no statistically significant difference between younger and older students in the view that the "Hit lists of popular music" project develops students' critical thinking in the field of music listening.

With the aid of the Mann-Whitney $U$ test, it was examined whether the attitudes of students of different ages differed with regard to the impact of the project "Hit lists of popular music" on the development of critical thinking in the field of music listening. The results indicate the absence of a difference between the two groups of students (Table 4, Figure 4, Chart 4), therefore the hypothesis is confirmed.

Table 4. Differences in attitudes about the influence of the "Hit lists of popular music" on the development of students' critical thinking in the field of listening to music with regard to age/grade

\begin{tabular}{|c|c|c|c|c|}
\hline Grade/Age & $\mathrm{C}$ & $\mathbf{U}$ & $\mathbf{z}$ & $\mathbf{p}$ \\
\hline 1st \& 2nd grade HS & 4.00 & \multirow{2}{*}{2607.50} & \multirow{2}{*}{-1.31} & \multirow{2}{*}{0.19} \\
\hline 3rd \& 4th grade HS & 4.32 & & & \\
\hline
\end{tabular}




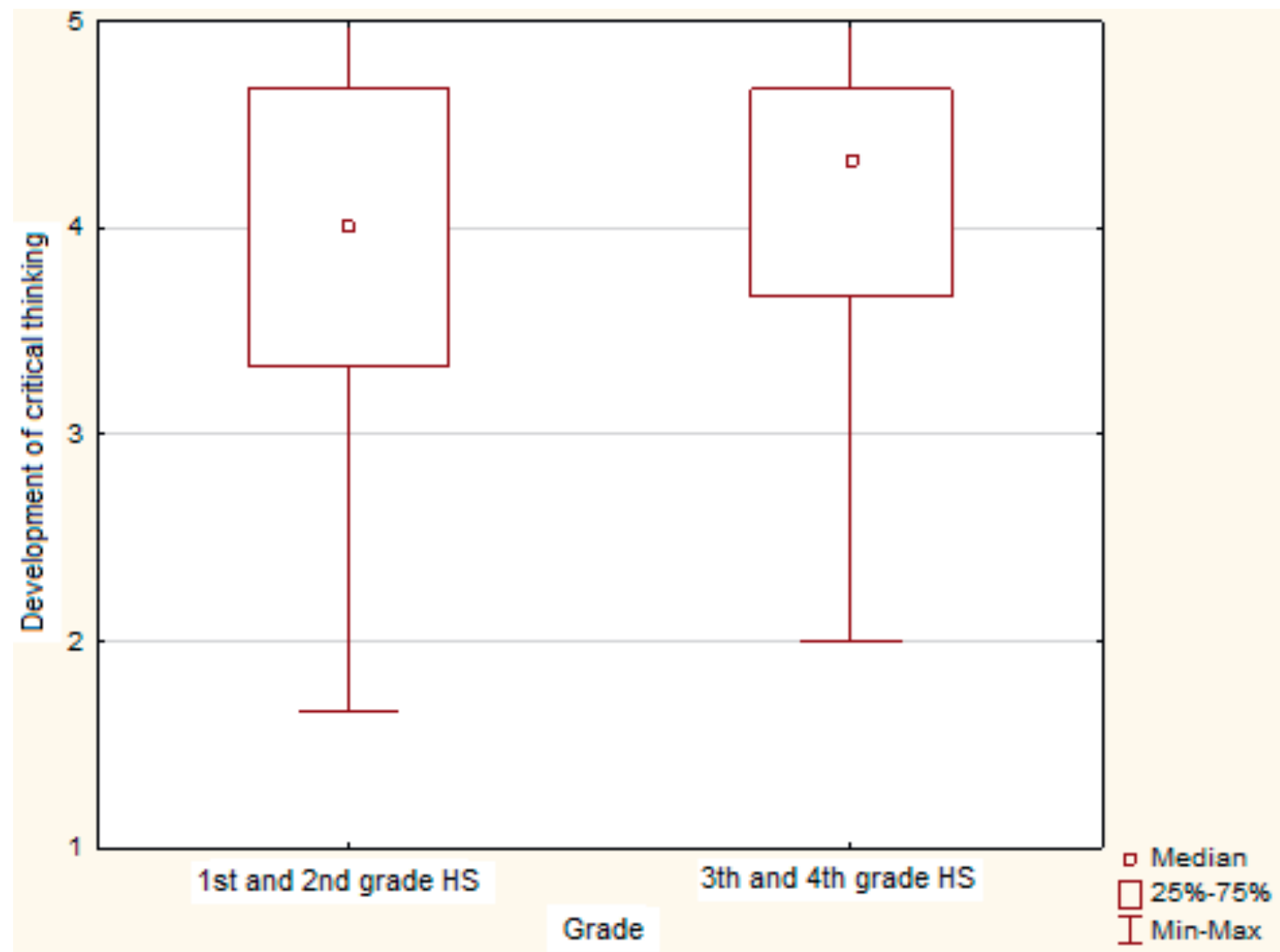

Figure 4. Differences in attitudes on the influence of "Hit lists of popular music" on the development of the students' critical thinking in the field of music listening with regard to age/grade

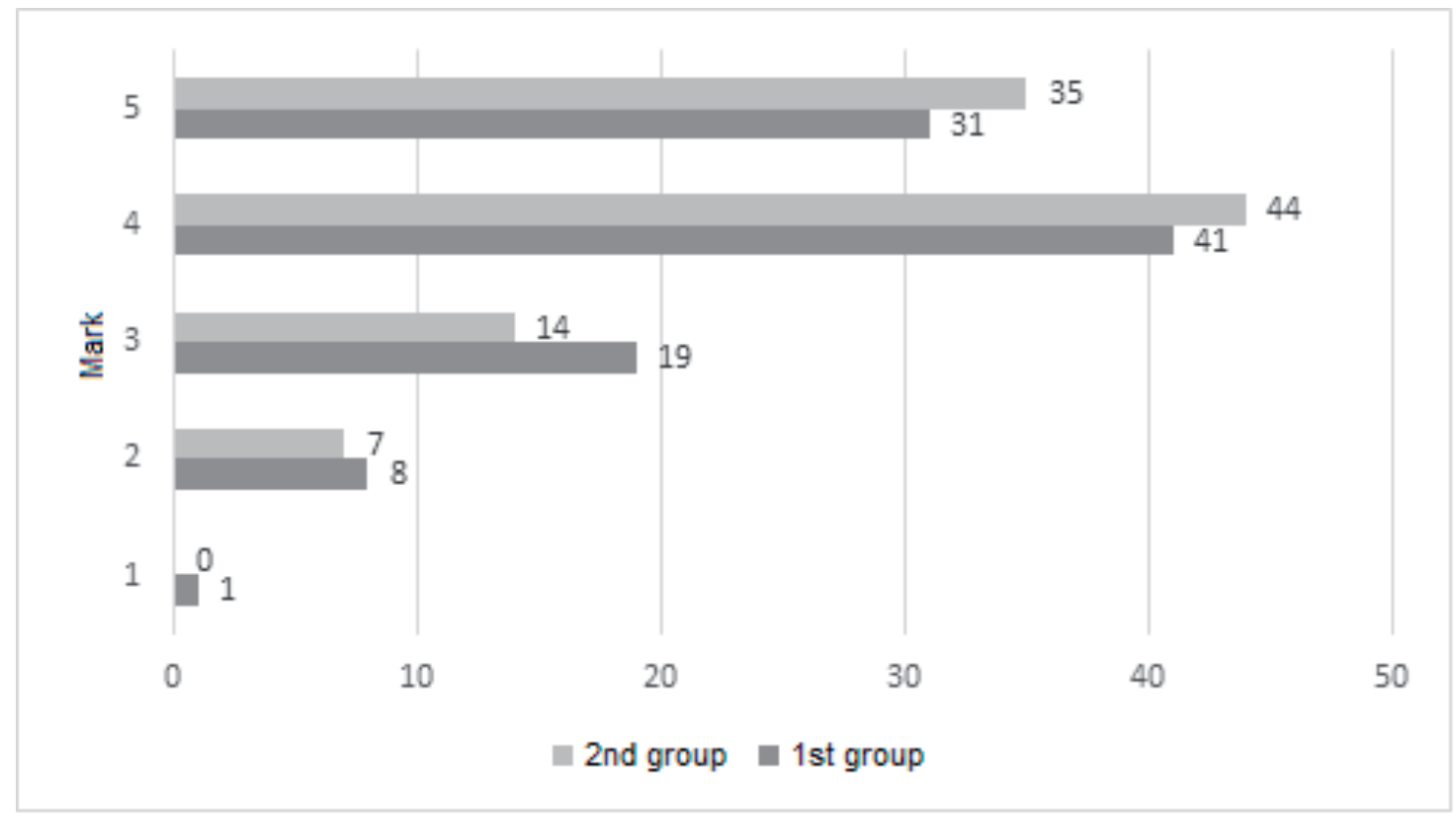

Chart 4. Display of the average percentage of students in groups 1 and 2 in the answers for a total of three questions of the second hypothesis 
The results showed that a large percentage of students, regardless of age, felt that the project had a positive impact on the development of their critical thinking in the field of music listening. The students were mostly thinking critically of the selection of songs for personal playlists and confirmed that with this approach in music teaching they developed a sensitivity to recognize the aesthetically valuable popular music that is offered to them in everyday life. Škojo (2019) thus points out that nowadays the media, especially modern means of sound production and reproduction, have enabled the mass dissemination of music and placed low-quality music at the center of young people's life habits. Music thus became omnipresent and accessible to all, and thus the influence of the mass media on musical preferences became dominant and leading in influence. He also believes that project activities and workshops in the field of music listening strategies can have a significant impact on the musical preferences of young people in order to develop a quality system of values and musical taste. Šulentić-Begić (2010) likewise believes that it is not enough for students to just remember data, but that the school should train them for a critical attitude towards the information presented to them at school, but also in their free time. Because: "It is the time of the media; and by that very penetrating, aggressive and intrusive in the way and content of consumption" (Previšić, 1998, 153).

H3: There is no statistically significant difference between younger and older students in the view that the "Hit lists of popular music" project develops students' musical taste and musical identity.

In order to test the set hypothesis, the Mann-Whitney $\mathrm{U}$ test was recalculated (Table 5, Figure 5, Chart 5). The results confirm the absence of a statistically significant difference between students of different ages with respect to the stated variable. Thus, the hypothesis is confirmed.

Table 5. Differences in attitudes on the impact of the project "Hit lists of popular music" on the development of musical taste and musical identity of students with regard to age/grade

\begin{tabular}{|c|c|c|c|c|}
\hline Grade/Age & $\mathrm{C}$ & $\mathrm{U}$ & $\mathbf{z}$ & $\mathbf{p}$ \\
\hline 1st \& 2nd grade HS & 4.15 & \multirow{2}{*}{2674.50} & \multirow{2}{*}{1.06} & \multirow{2}{*}{0.29} \\
\hline 3rd \& 4th grade HS & 3.99 & & & \\
\hline
\end{tabular}




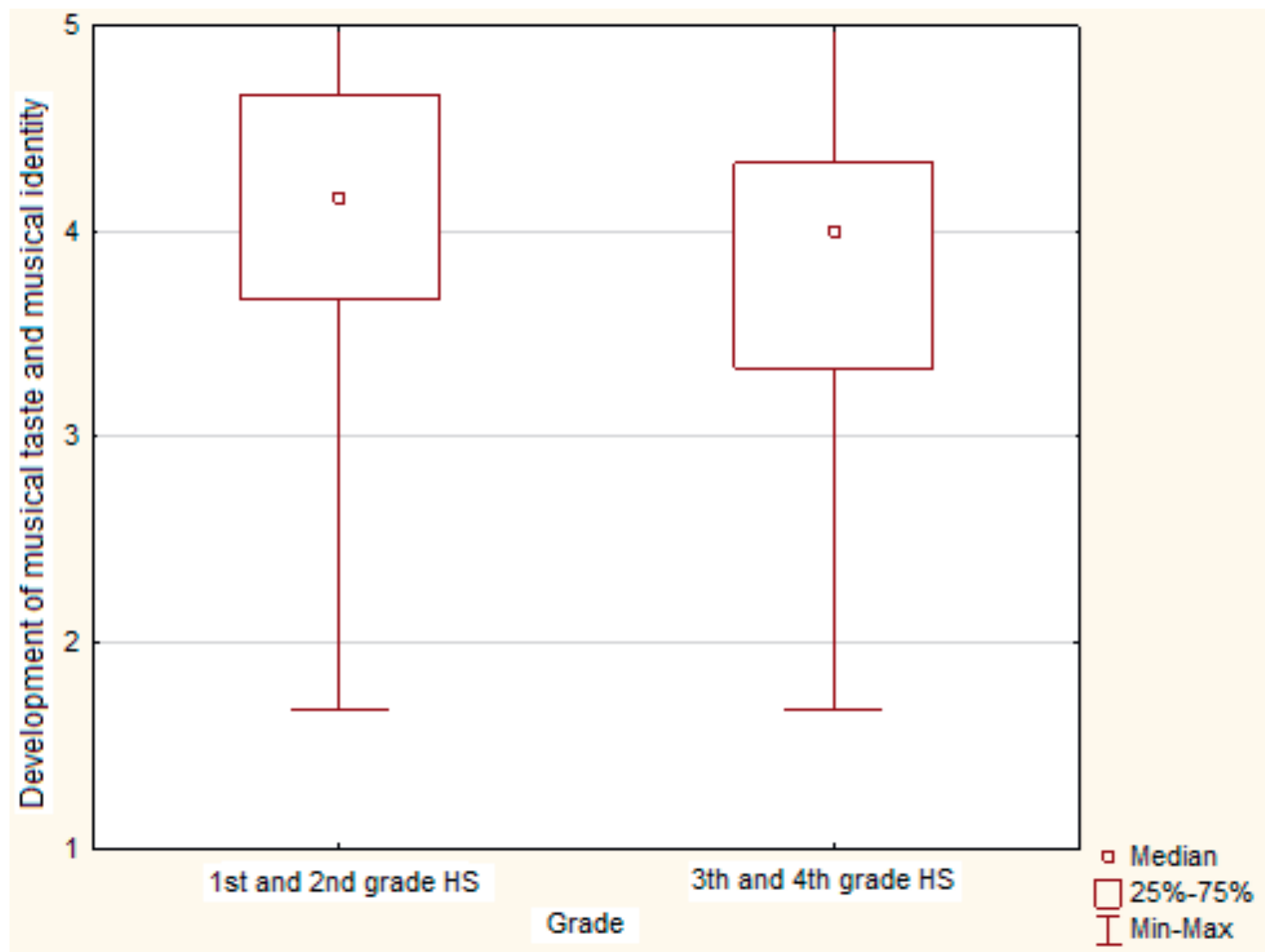

Figure 5. Differences in attitudes on the impact of the project "Hit lists of popular music" on the development of musical taste and musical identity of students with regard to age/class

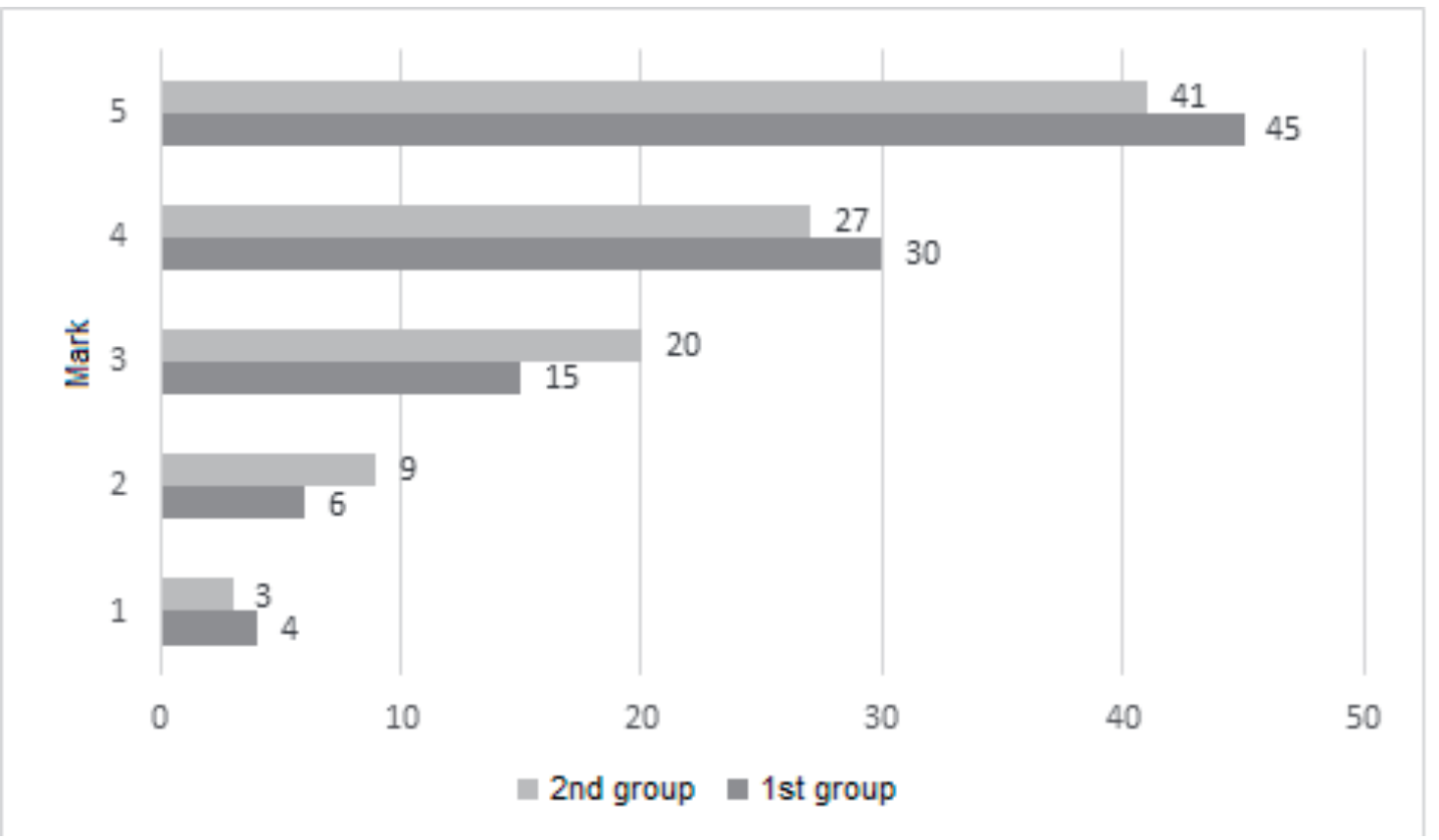

Chart 5. Display of the average percentage of students in groups 1 and 2 in the answers for a total of three questions of the third hypothesis 
In this section as well it was again found that regardless of age, the students were equally open to the introduction of a modern approach to music education which had a positive impact on the development of their musical taste (Chart 6). After the project, more than half of the students stated that they did not want to listen to music of lower/low aesthetic value and that in order to form a personal musical identity they planned to continue making and listening to playlists with aesthetically valuable music regardless of genre. Duraković and Vidulin-Orbanić (2013) believe that due to mass music production, the flood of music information is often inversely proportional to tradition and specific education, so the unprepared recipient is sometimes completely oriented towards public opinion and information released by the media. Consequently, a stratified audience is formed, both in terms of distinctive musical preferences and in terms of musical aesthetic profile. Therefore, these results indicate the possible impact of coordinated music teaching with a positive effect on the preferences of quality popular music, which may reduce the need for students to listen to less valuable popular music. In this way, it can pave the way for the preference of new "more demanding" directions in music such as jazz, film music, world music and finally classical music with the aim of aesthetically listening to these musical expressions in the students' free time.

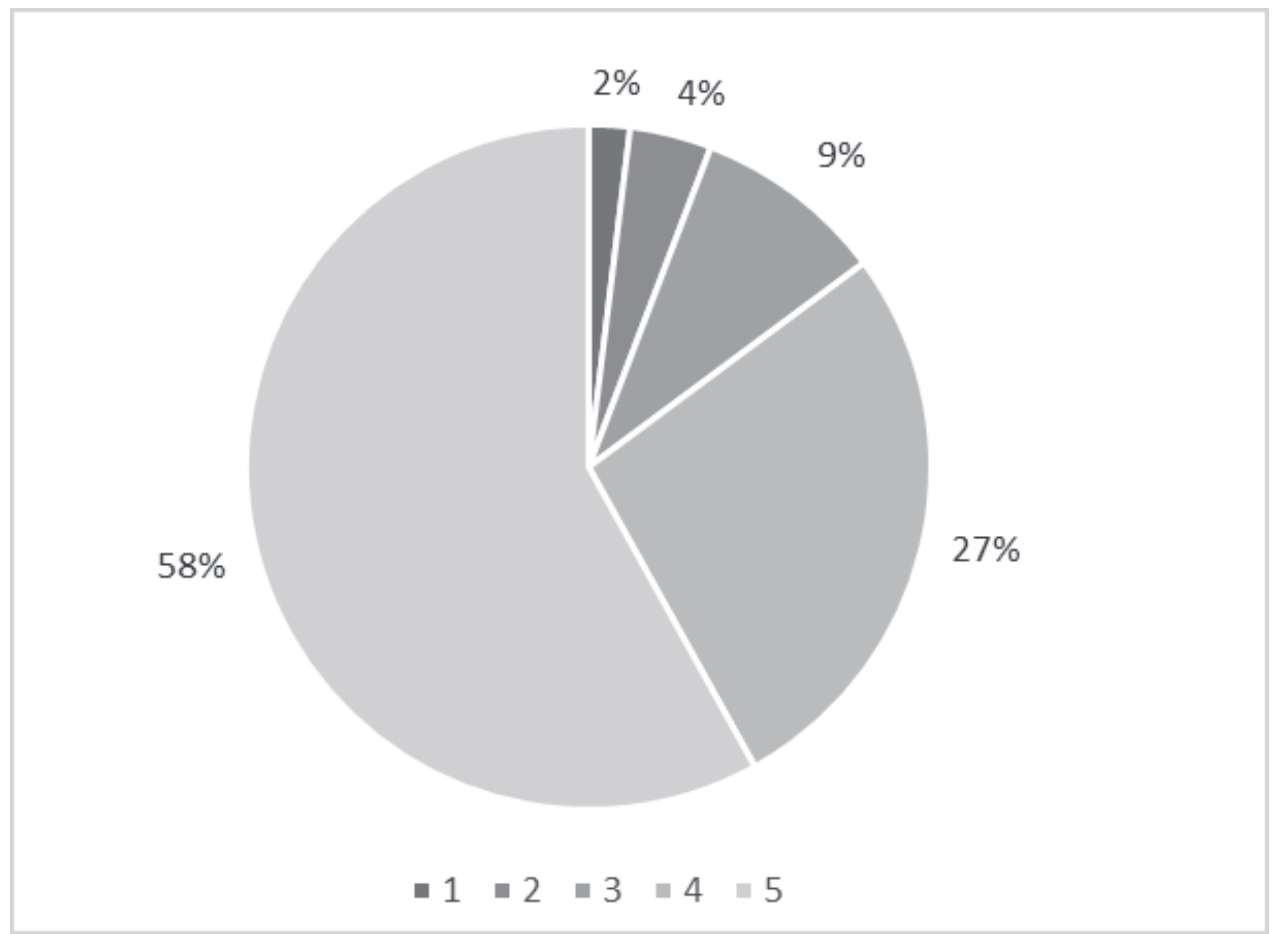

Chart 6. Answers to the question "I think that the project had a positive impact on the development of my musical taste" 
H4: There is no statistically significant difference between younger and older students in their openness to making and listening to playlists of aesthetically valuable music.

To test the set hypothesis, the Mann-Whitney $U$ test was recalculated. The results confirm the absence of differences between students of different ages given their openness to making and listening to playlists of aesthetically valuable music (Table 6, Figure 6, Chart 7), thus confirming the hypothesis.

Table 6. Differences in students' openness to making and listening to playlists of aesthetically valuable music with regard to age/class

\begin{tabular}{|c|c|c|c|c|}
\hline Grade/Age & $\mathrm{C}$ & $\mathbf{U}$ & $\mathbf{z}$ & $\mathbf{p}$ \\
\hline 1st \& 2nd grade HS & 4.32 & \multirow{2}{*}{2828.50} & \multirow{2}{*}{0.50} & \multirow{2}{*}{0.61} \\
\hline 3rd \& 4th grade HS & 4.32 & & & \\
\hline
\end{tabular}

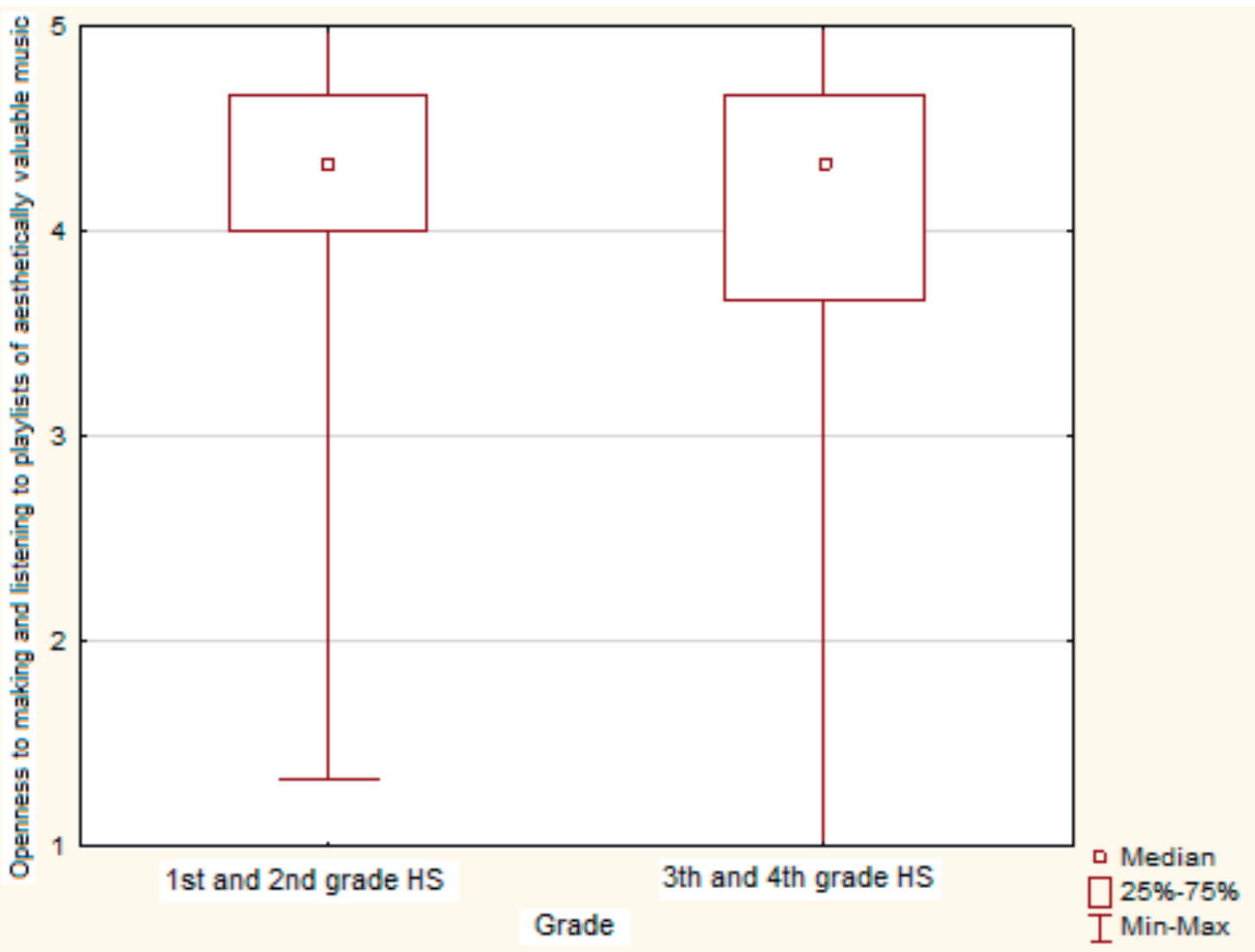

Figure 6. Differences in students' openness to making and listening to playlists of aesthetically valuable music with regard to age/class 


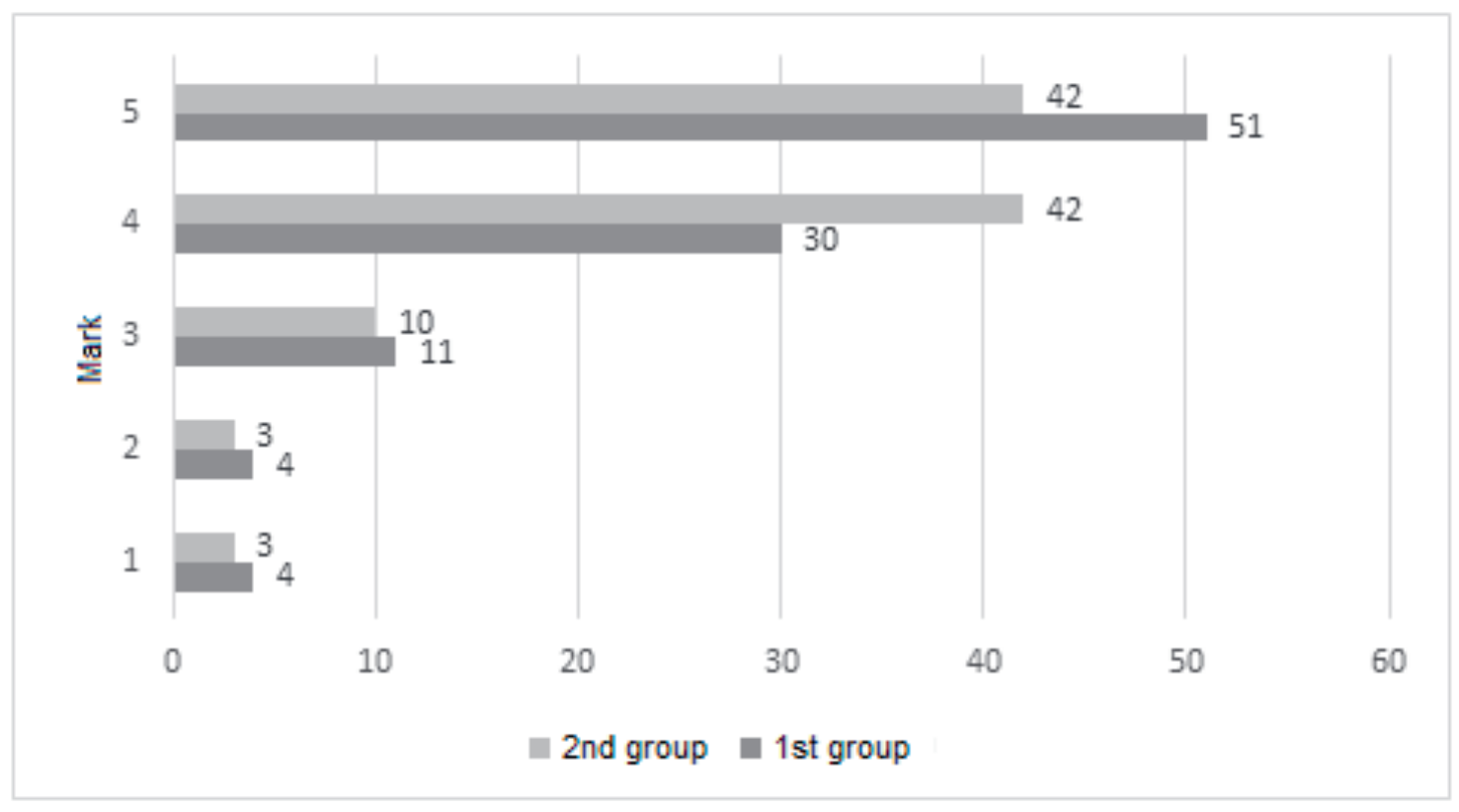

Chart 7. Display of the average percentage of students of groups 1 and 2 in the answers for a total of three questions of the fourth hypothesis

The results of the answer to the last hypothesis indicate that regardless of age, students are equally open to making and listening, and thus preferring aesthetically valuable popular music. Moreover, the vast majority stated that during the project they eagerly solved the tasks of selecting songs and making playlists, that in the future they planned to listen to playlists they had identified for this project and that they wanted to continue developing the project "hit list" to other music genres (film music, musical, jazz, ethno, crossover, classical music, etc).

The results of this research deviate from previous research on musical preferences in relation to the age of the listeners. Namely, the results of numerous studies confirm that younger students are more open to different musical styles, unlike older ones (Hargreaves, 1982). Observing the influence of maturation on musical preferences, LeBlanc (1991) used Hargreaves' notion of "open-earedness" and defined that: (1) children up to the age of eight can listen to a wide range of different musical styles; (2) openness decreases when entering adolescence; (3) at the transition from adolescence to early adulthood, openness increases again; (4) openness decreases as the listener matures and enters old age (Baltagi, 2006; LeBlanc, 1991; as cited in Dobrota, Reić Ercegovac, 2016). Thus, it can be concluded that adolescents are by nature, as they get older, more and more closed to discovering new musical expressions. Yet this project has shown that it is still possible to incite the entire population of high school students for more open research and preference for aesthetically valuable popular music. 


\section{CONCLUSION}

In today's mass media music environment, music listening is the basic way of musical behaviour, and the education of listeners and music experts is a first-class problem, not only of music teaching but of music culture in general because "mass production has brought unprecedented amounts of musical kitsch and musical worthlessness which young people consciously and without a critical attitude consume on a daily basis" (Rojko 2012,46). The project "Hit lists of popular music" is intended to expand the horizons of aesthetically valuable music for students, starting with popular expression, and then with other types of music. By placing numerous proven songs in one place, i.e. on an accessible and popular platform for music listening, a quality offer for music listening in one's free time is realized, which gives music teaching a new dimension in the education of students. Naturally, the encouragement of teachers and guidance in certain musical expressions and later insight into students' personal playlists for school purposes, is an indispensable factor for the dynamics of the process and, finally, success in developing students' musical taste.

With the aim to acquaint high school students with many popular songs of high aesthetic value, it was found that of a total of $61 \%$ of students listening to music of low aesthetic value, the project "Hit lists of popular music" fully or partially reduced the need to listen to such music in $50 \%$ of students. It was also found that by creating personal playlists on Spotify, students combined a large number of aesthetically valuable popular music, which in turn affected the increased need to listen to these songs, as well as the critical thinking during the discovery of new songs released by the media. The students stated that they were interested in solving the tasks related to the project and $81 \%$ of them wanted to continue developing the project in other musical directions.

Further, the students showed that they were open to a more modern model of teaching, focused on forming a musical identity and developing their musical taste through learning about music of different expressions, which is indicated by the fact that $85 \%$ think that their hit lists helped them develop a musical taste. All results of a total of four hypotheses confirmed that there is no statistically significant difference in the attitudes of younger and older groups of participants, which suggests that age, which is a major influencing factor of openness to new musical experiences, is not crucial for the development of critical thinking, musical taste and musical identity if music teaching is modernized and brought closer to the modern student.

Given that students often base their music preferences on emotions and the current mood, it is necessary to point out that interest, openness and attitudes 
towards quality, or attitudes towards low quality music, are key to shaping their musical taste and cultural identity. Therefore, critical music listening, which according to the so-called reception model which in high schools is taught through learning exclusively about art music, can be developed through more intensive introduction of different types of music (traditional, popular, jazz, ethno, world music, media music, peer music, film, crossover, etc.) and proportionally during all four years of high school music education. With such a more modern approach, and with the use of ICT, aesthetic education would become more important because students would certainly gain greater interest in the subject of Music art, develop more objective attitudes towards music and learn to establish value criteria in music listening. 


\section{REFERENCES}

1. Adorno T. W. (1962). Einleitung in die Musiksoziologie: zwolf theoretische Vorlesungen. Frankfurt am Main: Suhrkamp.

2. Andreis, J. (1967). Vječni Orfej. Zagreb: Školska knjiga.

3. Beckler, S. J., Allen R. B., Konečni, V. J. (1985). Mood-optimizing strategies in aesthetic-choice bahavior. Music perception, 2, 459-470.

4. Brđanović, D. (2014). Glazbene preferencije učenika srednje glazbene škole. Napredak, 154 (1-2), 47-64.

5. Buchberger, I. (2012). Kritičko mišljenje. Priručnik kritičkog mišljenja, slušanja, čitanja i pisanja. Rijeka: Udruga za razvoj visokoga školstva Universitas.

6. Bundra, J. I. (1993). A study of music listening processes through the verbal reports of schoolaged children. Doctoral thesis. Northwestern University, Evanston, IL.

7. Curriculum for primary school (2006). Zagreb: Ministry of Science, Education and Sports of the Republic of Croatia. Downloaded 11/3/2021 with: https://narodne-novine.nn.hr/clanci/sluzbeni/ full/2006_09_102_2319.html

8. Curriculum of the subject Music Culture for Primary Schools and Music Art for Gymnasiums in the Republic of Croatia (2019). Zagreb: Ministry of Science and Education of the Republic of Croatia. Downloaded 20/3/2021 with: https://narodne-novine.nn.hr/clanci/ sluzbeni/2019_01_7_151.html

9. Dobrota, S. (2012). Uvod u suvremenu glazbenu pedagogiju. Split: Faculty of Humanities and Social Sciences, University of Split.

10. Dobrota, S., Kuščević, D. (2009). Glazbeni identiteti u kontekstu popularne glazbe. Godišnjak Titius, 2 (2), 195-206. Downloaded 23/5/2019 with: https://hrcak.srce.hr/112448

11. Dobrota, S., Reić Ercegovac, I. (2009). Glazbene preferencije mladih s obzirom na neke sociodemografske varijable. Odgojne znanosti, 11 (2), 129-146.

12. Dobrota, S., Reić Ercegovac, I. (2016). Zašto volimo ono što slušamo: glazbeno-pedagoški i psihologijski aspekti glazbenih preferencija. Split: Faculty of Humanities and Social Sciences, University of Split.

13. Dobrota, S., Senjan, I. (2018). The impact of The Reciprocal feedback model of musical response on shaping students' musical taste. The journal of music education of the Academy of music in Ljubljana, 28, 5-27.

14. Dobrota, S., Tomić Ferić, I. (2006.). Sociokulturalni aspekti glazbenih preferencija studentica studija za učitelje primarnog obrazovanja u Splitu. Odgojne znanosti, 8 (1), 263-278.

15. Duraković, L., Vidulin-Orbanić S. (2013). Studentska populacija i napisi o glazbi: mediji, kriteriji i žanrovske preferencje. In S. Vidulin-Orbanić (Ed.) Glazbena pedagogija u svjetlu sadašnjih i budućih promjena-3 (pp. 23-39). Pula: Juraj Dobrila University of Pula.

16. Frith, S. (1996). Performing Rites. Oxford: Oxford University Press.

17. Gregory, D. (1994). Analysis of listening preference of high school and college musicians. Journal of Research in Music Education, 42, 331-342. doi:10.2307/3345740 
18. Hargreaves, D. J. (1982). The development of aesthetic reactions to music. Psychology of Music, Special Issue, 51-54.

19. Hargreaves, D. J., Colman, A. M. (1981). The dimensions of aesthetic reactions to music. Psychology of Music, 9, 15-20. doi: 10.1177/03057356810090010301

20. Hargreaves, D. J., MacDonald, R. A. R., Miell, D. E. (2005). How do people communicate using music?. In D. E. Miell, R. A. R. MacDonald, D. J. Hargreaves (Eds.) Musical Communication (pp. 1-25). Oxford, UK: Oxford University Press. Downloaded 1.07.2015. with: http://dx.doi. org/10.1093/acprof:oso/9780198529361.003.0001

21. Hedden, S. K. (1973). Listeners' Responses to Music in Relation to Autochthonous and Experiential Factors. Journal of Research in Music Education, 21 (3), 225-238. Downloaded 10.01.2017. with: http://journals.sagepub.com/doi/pdf/10.2307/3345092

22. Johnson, D. C. (2004). Music Listening and Critical Thinking: Teaching Using a Constructivist Paradigm. International Journal of the Humanities, 2 (2), 1161-1169. Downloaded 10.2.2017. with: https://libres.uncg.edu/ir/uncw/listing.aspx?id=9217

23. Johnson J. K., Chang C.-C., Brambati S. M., Migliaccio R., Gorno-Tempini M. L., Miller B. L., Janata, P. (2011). Music recognition in frontotemporal lobar degeneration and Alzheimer disease. Cognitive and behavioral neurology, 24 (2), 74-84. doi: 10.1097/WNN.0b013e31821de326

24. Kalauz, M. (2018). Turbofolk u Dubrovniku: mladi, tranzicija i životni stilovi (thesis, University of Zagreb). Repository of the Faculty of Political Science in Zagreb. Downloaded 16/3/2021 with: https://repozitorij.fpzg.unizg.hr/islandora/object/fpzg\%3A825/datastream/PDF/view

25. Kemp, A. E. (1997). Individual differences in musical behaviour. In D. J. Hargreaves, A. C. Nort (Eds.) The social psychology of music (pp. 25-45). New York: Oxford Univesity Press.

26. Kline, J. A. (1993). Listening effectively. Alabama: Air University Press.

27. Klooster, D. (2003). Što je kritičko mišljenje? Metodički ogledi, 9 (2), 87-95.

28. Knowles, M. (1980). The Modern Practice of Adult Education. Chicago, IL: Follett.

29. LeBlanc, A. (1991). Effect of maturation/aging on music listening preference: a review of the literature. From Ninth National Symposium on Research in Music Behaviour 3th-7th March 1991, Canon Beach, Oregon, USA.

30. Madsen, C. K., Geringer, J. M. (2000/2001). A focus of attention model for meaningful listening. The Bulletin of the Council for Research in Music Education, 147, 103-108.

31. Meyers, C. (1986). Teaching Students to Think Critically. San Francisco, CA: Jossey-Bass.

32. Moore, R., Johnson, D. (2001). Effects of musical experience on perception of and preference for humor in Western art music. Bulletin of the Council for Research in Music Education, 149, 31-37.

33. National Curriculum for Early and Preschool Education (2012). Zagreb: Ministry of Science, Education and Sports of the Republic of Croatia. Downloaded 11/3/2021 with: https://mzo.gov. $\mathrm{hr} /$ UserDocsImages//dokumenti/Obrazovanje/Predskolski//Nacionalni\%20kurikulum\%20za\%20 rani\%20i\%20predskolski\%20odgoj\%20i\%20obrazovanje\%20NN\%2005-2015.pdf

34. North, A. C., Hargreaves, D. J. (1995). Subjective complexity, familiarity, and liking for popular music. Psychomusicology, 14, 77-93. doi: 10.1037/h0094090

35. North, A. C., Hargreaves, D. J., O'Neill, S. (2000). The importance of music to adolescents. British Journal of Educational Psychology, 70 (2), 255-272. doi: 10.1348/000709900158083 
36. O’Brien, J. P. (1987). The Listening Experience. New York: Schirmer Books.

37. Paul, R. W. (1993). Critical Thinking: How to Prepare Students for a Rapidly Changing World. Santa Rosa, CA: Foundation for Critical Thinking.

38. Požgaj, J. (1950). Metodika muzičke nastave. Zagreb: Nakladni zavod Hrvatske.

39. Previšić, V. (1998). Doprinosi “alternativnih škola” kvaliteti odgoja i obrazovanja. In V. Rosić (Ed.) Kvaliteta u odgoju i obrazovanju (pp. 148-154). Rijeka: Faculty of Education in Rijeka.

40. Rentfrow, P. J., Gosling, S. D. (2003). The do re mis of everyday life: Examining the structure and personality correlates of music preferences. Journal of Personality and Social Psychology, 84 (6), 1236-1256.

41. Robinson, P. (2009). Examining and defining the term 'musical culture' stemming from secondary curricula. Published dissertation. The University of Melbourne. Downloaded 13/12/2017. with: https://minerva-access.unimelb.edu.au/bitstream/handle/11343/35488/264183Robinson1. pdf?sequence $=1$

42. Rojko, P. (1996). Metodika nastave glazbe, teorijsko tematski aspekti. Osijek: Josip Juraj Strossmayer University of Osijek.

43. Rojko, P. (2007). Znanje o glazbi nasuprot glazbenom znanju. Tonovi, 49 (1), 71-87.

44. Rojko, P. (2012). Metodika nastave glazbe. Teorijsko tematski aspekti. E-knjiga. Osijek: Josip Juraj Strossmayer University of Osijek.

45. Senjan, I. (2018a). Nastava glazbe u hrvatskim općeobrazovnim srednjim školama. Metodički ogledi, 24 (1), 31-72.

46. Senjan, I. (2018b). Suvremeni pristup oblikovanju glazbenoga ukusa učenika u nastavi glazbene umjetnosti. Život i škola, LXIV (2), 77-100. https://doi.org/10.32903/zs.64.2.6

47. Senjan, I. (2018c). Usporedba djelovanja Modela recipročnog odgovora i Dijakronijskog modela u nastavi glazbene umjetnosti na oblikovanje glazbenog ukusa učenika, Doctoral thesis, Faculty of Humanities and Social Sciences, Zagreb.

48. Sims, W. (1990). Sound approaches to elementary music listening. Music Educators Journal, 77 (4), 38-42.

49. Smith, J. D. (1987). Conflicting aesthetic ideals in a musical culture. Music perception, 4, 373-391. doi: $10.2307 / 40285380$

50. Surkova, M. (2012). The Effects of Personality and Creativity on Uses of Music. Graduation thesis. DBS School of Arts, Dublin, Department of Psychology. Downloaded 11/7/2017 with: http:// esource.dbs.ie/bitstream/handle/10788/455/ba_surkovam_m_2012.pdf?sequence=1

51. Škojo, T. (2010). Sinkronijski model nastave glazbene umjetnosti i njegova usporedba s dijakronijskim modelom. Magistarski rad. Sveučilište u Zagrebu, Muzička akademija, Odsjek za glazbenu pedagogiju, Filozofski fakultet, Odsjek za pedagogiju.

52. Škojo, T. (2016). Glazbene preferencije učenika kao polazište za realizaciju izvannastavnih aktivnosti u strukovnim školama. Život i škola, LXII (2), 167-184. Downloaded 10/9/2021 with: https://hrcak.srce.hr/179035

53. Škojo, T. (2019). Odnos glazbenih preferencija srednjoškolaca, glazbenog obrazovanja i sociodemografskih varijabli. Metodički ogledi, 26 (2), 33-58. https://doi.org/10.21464/mo.26.2.5 
54. Šulentić Begić, J. (2006). Primjena otvorenoga modela nastave glazbe. Život i škola: časopis za teoriju i praksu odgoja i obrazovanja, 52 (15-16), 97-104. Downloaded 22/5/2016 with: https:// hrcak.srce.hr/25034

55. Šulentić Begić, J. (2010). Slušanje glazbe u osnovnoškolskoj nastavi. In A. Bene (Ed.) Zbornik radova s IV. International Scientific Conference - Modern Methodological Aspects / Korszerü módszertani kihívások/Suvremeni metodički izazovi (pp. 429-441). Subotica: Újvidéki Egyetem, Magyar Tannyelvü Tanitóképzö Kar.

56. Vidulin-Orbanić, S. (2002). Refleksije na današnji školski milje s naglaskom na promjene u nastavi glazbe. Tonovi, 40 (1), 55-70.

57. Vukasović, A. (2001). Pedagogija. Zagreb: Hrvatski katolički zbor „Mi“.

58. Woodford, P. G. (1995). Critical thinking in music. Canadian Music Educator, 37 (1), 36-40.

\section{Internet sources}

1. Jokić, B. (2021). Turbofolk u novom normalnom: Koga briga jesu li im u slušalicama Bane Bojanić, Beethoven, Štulić, Daft Punk ili Tram 11... Sve dok čiste iza sebe. Downloaded 7/3/2021 with: https://www.tportal.hr/komentatori/clanak/turbofolk-u-novom-normalnom-koga-brigajesu-li-im-u-slusalicama-bane-bojanic-beethoven-stulic-daft-punk-ili-tram-11-sve-dok-ciste-izasebe-foto-20210306

2. Profil Klett (2021). Metodički kutak. https://www.profil-klett.hr/metodicki-kutak (1/6/2021)

3. Platforma za slušanje glazbe Spotify. Available on: https://www.spotify.com/hr-hr/ (1/6/2021)

4. Cambridge Dictionary. Available on: https://dictionary.cambridge.org/ (4/6/2021)

\section{Oral sources}

1. Personal interview of educators Markovica, D. and Švetak, T. DV Maslačak, Đurđevac (15/3/ 2021) 


\section{SLUŠANJE GLAZBE S GILJEM RAZVOJA GLAZBENE KULTURE UČENIKA SREDNJE ŠKOLE}

\section{SAŽETAK}

Promatrajući društvo u cjelini, glazbene potrebe pojedinca najčešce se očituju kroz aktivno muziciranje i slušanje pretežno popularne/zabavne vrste glazbe. Osobna glazbena kultura i preferencije prema određenom glazbenom izričaju razvijaju se od najranije životne dobi te se oblikuju tijekom cijeloga života. $U$ radu se promišlja područje slušanja glazbe tijekom glazbenoga odgoja $i$ obrazovanja od ranoga $i$ predškolskoga odgoja i obrazovanja pa do završetka srednje škole s ciljem uvida u tijek kontinuiranoga glazbenog razvoja učenika u tome području. Prikazuje se i projekt Gimnazije dr. Ivana Kranjčeva Đurđevac "Liste hitova popularne glazbe“ kojim se učenike srednje škole potiče na uporabu masovnih medija u smislu izrade tzv. playlista na streaming platformama za slušanje glazbe. Rezultati ankete pokazali su da se na taj način u svekolikoj ponudi različitih glazbenih izričaja ipak može učenike kontrolirano usmjeravati na otkrivanje i preferiranje estetski vrijedne glazbe te se može pozitivno utjecati na razvoj njihova kritičkoga mišljenja i osobnoga glazbenog identiteta.

Ključne riječi: estetski odgoj, glazbeni identitet, kritičko mišljenje, liste hitova popularne glazbe, playliste. 